\title{
Light to Hydrogen: Photocatalytic Hydrogen Generation from Water with Molecularly-Defined Iron Complexes
}

\author{
Henrik Junge ${ }^{1}$, Nils Rockstroh ${ }^{1}$, Steffen Fischer ${ }^{2}$, Angelika Brückner ${ }^{1}$, Ralf Ludwig ${ }^{1,2}$, \\ Stefan Lochbrunner ${ }^{3}$, Oliver Kühn ${ }^{3}$ and Matthias Beller ${ }^{1, *}$ \\ 1 Leibniz Institute for Catalysis, University of Rostock (LIKAT), Albert-Einstein-Straße 29a, \\ 18059 Rostock, Germany; Henrik.Junge@catalysis.de (H.J.); Nils.Rockstroh@catalysis.de (N.R.); \\ Angelika.Brueckner@catalysis.de (A.B.) \\ 2 Institute of Chemistry, Department Physical Chemistry, University of Rostock, Dr.-Lorenz-Weg 1, \\ 18059 Rostock, Germany; Steffen.Fischer@uni-rostock.de (S.F.); Ralf.Ludwig@uni-rostock.de (R.L.) \\ 3 Institute of Physics, University of Rostock, Albert-Einstein-Straße 23-24, 18059 Rostock, Germany; \\ Stefen.Lochbrunner@uni-rostock.de (S.L.); Oliver.Kuehn@uni-rostock.de (O.K.) \\ * Correspondence: Matthias.Beller@catalysis.de; Tel.: +49-381-1281-113
}

Academic Editor: Matthias Bauer

Received: 27 January 2017; Accepted: 27 February 2017; Published: 9 March 2017

\begin{abstract}
Photocatalytic hydrogen generation is considered to be attractive due to its combination of solar energy conversion and storage. Currently-used systems are either based on homogeneous or on heterogeneous materials, which possess a light harvesting and a catalytic subunit. The subject of this review is a brief summary of homogeneous proton reduction systems using sacrificial agents with special emphasis on non-noble metal systems applying convenient iron(0) sources. Iridium photosensitizers, which were proven to have high quantum yields of up to $48 \%$ (415 nm), have been employed, as well as copper photosensitizers. In both cases, the addition or presence of a phosphine led to the transformation of the iron precursor with subsequently increased activities. Reaction pathways were investigated by photoluminescence, electron paramagnetic resonance (EPR), Raman, FTIR and mass spectroscopy, as well as time-dependent DFT-calculations. In the future, this knowledge will set the basis to design photo(electro)chemical devices with tailored electron transfer cascades and without the need for sacrificial agents.
\end{abstract}

Keywords: hydrogen; iron; copper; hydrogenases; photosensitizer; photocatalysis; water splitting; spectroscopy

\section{Introduction}

An increasing number of pilot plants combining wind mills or photovoltaic devices with classical water electrolysis is installed all over the world. This reflects the progressive contribution of the renewable energies wind and sunlight to a sufficient and sustainable energy supply [1-4] and thereby raises the necessity to store the harvested electric energy due to its fluctuating occurrence. In this respect, hydrogen is of particular interest as the primary product of the interconversion of electric and chemical energy, as well as a secondary energy carrier [1-4]. Besides the hydrogen generation from water, also its storage and back conversion to electrical energy are current topics of intensive research [1-7]. A more efficient way for the conversion of the Sun's energy to hydrogen compared to the combination of photovoltaic devices with water electrolysis [8-17], which possesses an overall efficiency between $10 \%$ and $14 \%[18,19]$, may constitute the direct photocatalytic water splitting into hydrogen and oxygen. So far, the two half reactions water oxidation and water reduction are mainly studied separately. Disadvantageously, this requires the application of sacrificial reagents (SR) as 
electron donors or electron acceptors (Scheme 1) [11-17,20-29]. On the other hand, it allows for a simplification of the complex system of overall water splitting and hence a more detailed understanding of the basic processes as a prerequisite for improvements. Within the development of more efficient and stable catalyst systems for photocatalytic hydrogen generation from water, an additional trend towards the usage of $3 \mathrm{~d}$ metals is obvious. This is motivated by several advantages of such catalysts due to lower costs and higher abundance compared to noble metals. Exemplarily, significant efforts have been reported applying cobalt and nickel complexes as proton reduction catalysts (WRC) (Although the term "water reduction catalyst" as well as the related abbreviation WRC is commonly used in relevant literature it should be named proton reduction catalyst in the strict sense) [30-40]. For example, various groups investigated cobaloxime-based catalysts [25,31]. Recently, these systems have been outperformed by pentapyridyl cobalt complexes achieving a turnover number (TON) with respect to Co of up to 11,000 with a Re-photosensitizer (PS) and ascorbic acid (SR) [36]. Prominent examples of nickel catalysts constitute the DuBois catalyst [37], as well as tris(2-pyridylthiolate) [38], 2-aminobenzenethiolate, 2-mercaptophenolate and 2-mercaptopyridyl- $N$-oxide [39] nickel complexes by Eisenberg. The DuBois system showed excellent activity with a TOF up to $100,000 \mathrm{~s}^{-1}$ in the electrocatalytic hydrogen evolution reaction (HER) [41,42]. However, in photocatalytic hydrogen generation, this system achieved only a TON $\mathrm{Ni}_{\mathrm{i}}$ of 2700 over $150 \mathrm{~h}$ with Ru photosensitizer $\mathbf{A}$ and ascorbic acid (SR) [37], while applying thiolate nickel complexes improved the $\mathrm{TON}_{\mathrm{Ni}}$ up to 7300 after $30 \mathrm{~h}$ with fluorescein, a xanthene-type organic dye, as the photosensitizer and TEA as SR [40]. A stability of more than $100 \mathrm{~h}$ was obtained using this system with TEOA as the electron donor [39]. More than 280,000 turnovers were obtained by replacing the PS and SR by water-soluble CdSe quantum dots and ascorbic acid, respectively [39]. Very recently, also stabilized nickel [43], iron [44], zinc [45] and copper nanoparticles [46] were reported to constitute active WRC in the photocatalytic hydrogen generation from water.
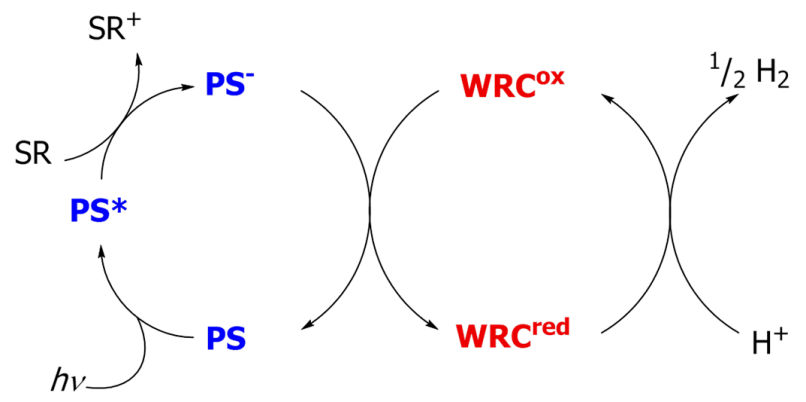

Scheme 1. The basic concept of hydrogen generation from water (hydrogen half reaction) via a reductive quenching pathway applying a photosensitizer (PS) and a proton reduction catalyst (WRC) in the presence of the sacrificial reductant (SR).

In this review, we present a brief overview about iron-based WRC, including noble metal-free PS systems. Exemplarily, mechanistic investigations and the working mode of a selected system by employing a tool of combined analytical methods are summarized.

\section{Overview of Molecularly-Defined Iron WRCs and the Respective Photosensitizers}

Iron is a very important and abundant base metal constituting, e.g., the active centers in hydrogenases [47-49] and showing impressive activities for hydrogen generation and cleavage with up to 9000 molecules $\mathrm{H}_{2}$ per second and site [50]. Because of this outstanding activity, especially $[\mathrm{FeFe}]$ hydrogenases have attracted much attention for more than a decade, although the real structure regarding the central atom of the dithiolate bridge was identified to be nitrogen only in 2009 [51,52]. Thus, besides $\mathrm{CO}$ and $\mathrm{CN}$ ligands, the dinuclear iron complex contains an internal base, which is of fundamental importance since it allows for the heterolytic splitting/formation of $\mathrm{H}_{2}$ by metal ligand 
cooperative catalysis. This principle has also been adopted for other (de)hydrogenation reactions applying non-innocent ligand iron complexes [53-60].

Inspired by the above-mentioned lead structure several groups, e.g., Wang and Sun [61,62], as well as Hammarström [23], Ott [63] and Reek [64] successfully developed a variety of Fe-based WRC, which resulted in catalyst turnover numbers of up to 466 regarding Fe (Scheme 2). An overview of the applied PS is provided in Scheme 3; selected conditions and TONs are listed in Table 1. It should be noted here that a direct comparison of turnover numbers is sometimes intricate as it depends on the concentration of the involved components, i.e., WRC, PS and SR.

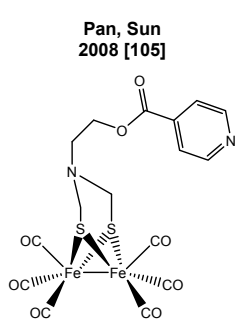

1
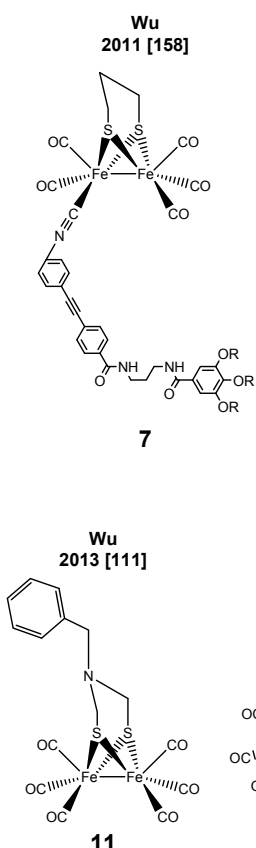

11

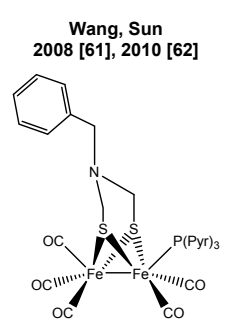

2

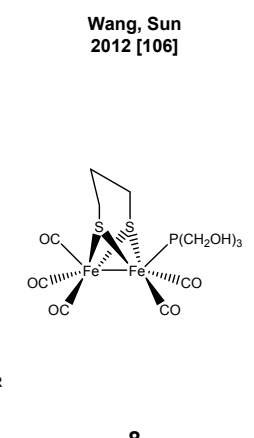

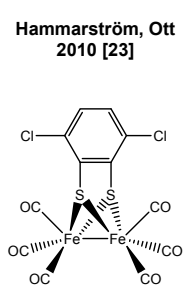

3

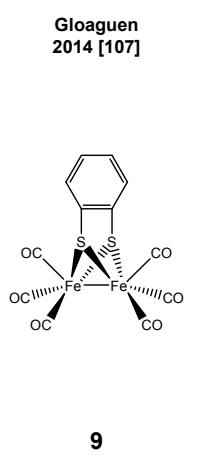

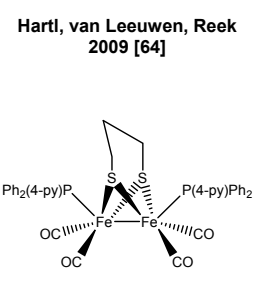

4

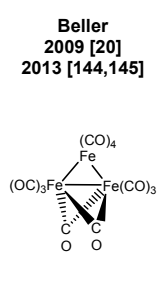

5

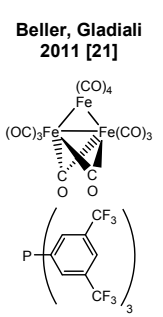

6

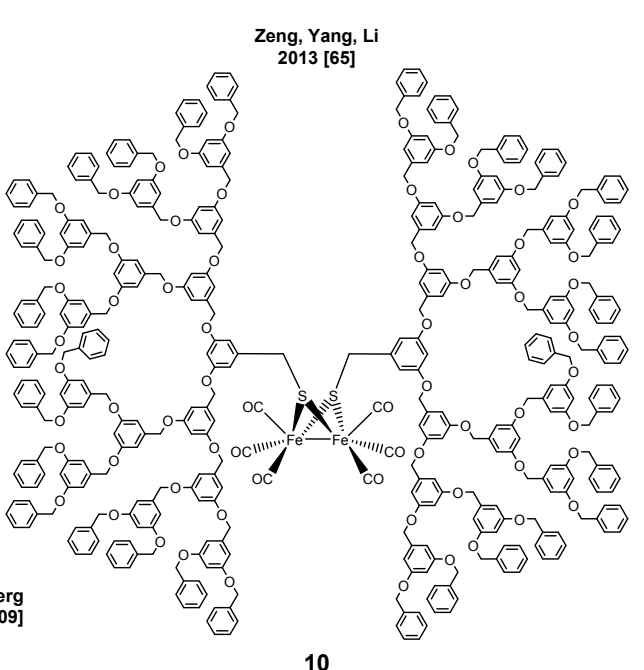

10

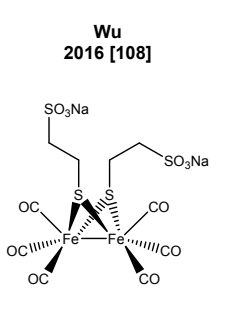

Lochbrunner, 2016 [157]
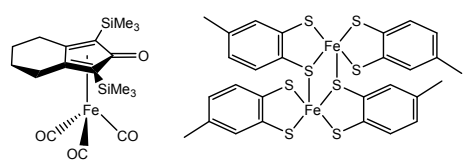

13

14

Scheme 2. Iron-based WRCs inspired by hydrogenases. Turnover numbers (TONs) with respect to the WRC are reported in Table 1. The used photosensitizers (PS) are shown in Scheme 3.

In 2013, Yu et al. reported a TON of 22,200 with a dendrimer-based diiron hydrogenase mimic applying only $10 \mathrm{nmol}$ of the catalyst [65]. The same year, other mimics were applied for visible light-driven hydrogen production embedded in a MOF [66] or later in a protein matrix [67]. However, in these cases, productivities (TON) of only ca. 5 and 130, respectively, were achieved in the presence of Ru-PS B (Scheme 3).

Besides the WRC, the photosensitizer (PS) is a second important component in water reduction. For this purpose, especially ruthenium complexes have played a key role since the 1970s [68-74], later followed by various iridium [75,76], platinum [77-79] and rhenium [80-85] complexes. In contrast, more abundant metals or even metal-free photocatalytic systems were reported: examples include, e.g., iron [86], zinc [24,25,87-89] and magnesium-based [24,90-94] photosensitizers, CdTe [95], CdSe [39] or carbon [96] quantum dots or organic dyes [38-40,97-104] together with either cobalt or nickel catalysts. 
Mostly, the reported activities and stabilities were still low. However, Eisenberg recently reported a TON for a nickel WRC as high as 280,000 together with water-soluble CdSe quantum dots with tripodal S-donor capping agents as PS and ascorbic acid as the sacrificial electron donor at pH 4.5 [39].

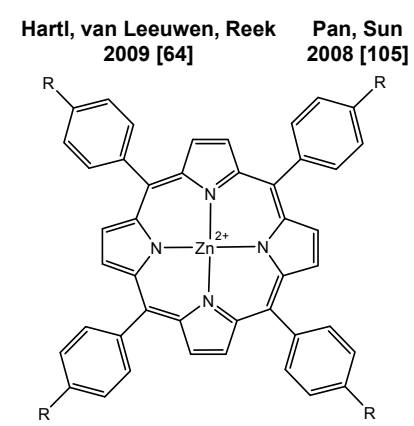

A

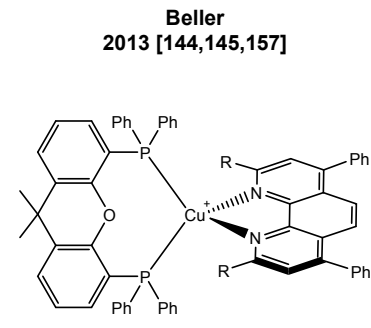

D

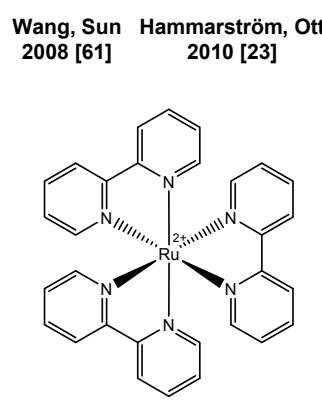

B
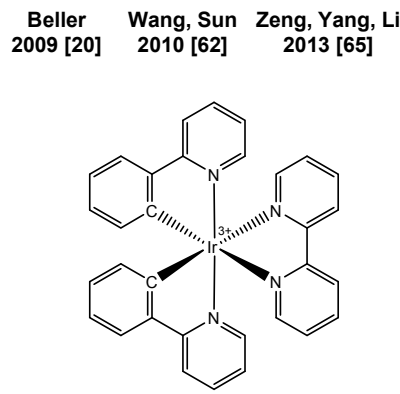

C
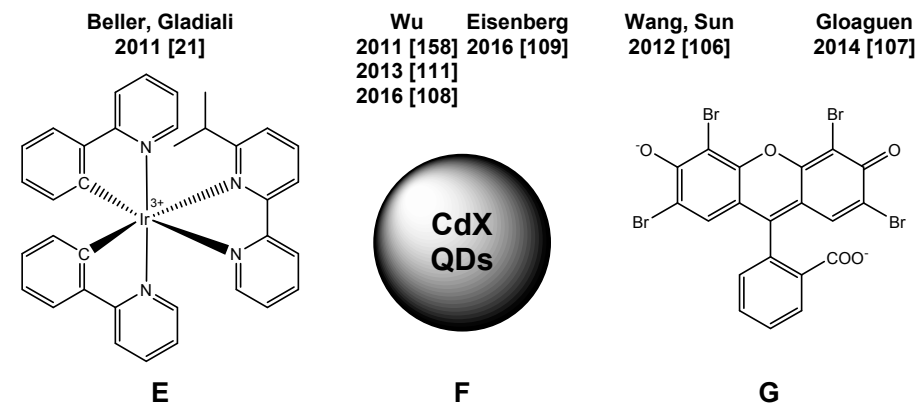

Scheme 3. Photosensitizers (PS) applied in iron-based water reduction systems with the WRCs depicted in Scheme 2. TONs with respect to the photosensitizer are reported in Table 1.

A few of the above-mentioned iron-based WRC were also used as a part of fully noble metal-free water reduction systems applying either $\mathrm{Zn}$ porphyrins $[64,105]$ or organic dyes $[106,107]$ instead of Ru-PS $[23,61]$ and Ir-PS [62]. Applying the latter (i.e., $\mathrm{EY}^{2-}$ ) in a micellar solution resulted in a TON of 117 (Scheme 2: 9, Scheme 3: G) [107].

Very recently, CdSe quantum dots were independently successfully applied as light-harvesting units by $\mathrm{Wu}$ [108] and Eisenberg [109] in a system containing different [FeFe]-Hydrogenase mimics (Scheme 2, 12 and 14). In both cases, outstanding TONs of 26,500 and 29,400, respectively, were obtained. Applying $\left[\mathrm{Ru}(\mathrm{bpy})_{3}\right]^{2+}$ as PS resulted in a comparably low TON of only 178 [108]. In addition, co-embedded CdSe quantum dots and the [FeFe]-hydrogenase mimic in lipid membranes were used, however resulting in a much lower TON of 651 [110]. As an alternative, also CdTe quantum dots were applied resulting in the hitherto highest observed $\mathrm{TON}_{\mathrm{Fe}}$ as high as 52,800 [111] for $\mathbf{1 1}$ (Scheme 2).

All of these results might be compared, e.g., with the use of an isolated [NiFe] hydrogenase in visible light-driven hydrogen production on $\mathrm{C}_{3} \mathrm{~N}_{4} / \mathrm{TiO}_{2}$ with an excellent productivity (TON) of 580,000 [112].

Surprisingly, the promising application of copper (I) complexes with polypyridine ligands as photosensitizers has been neglected for a long time with only one early communication from the group of Sauvage [113]. As their photo- and electro-chemical properties have been known for decades, they are already applied as active components in organic light-emitting diodes (OLEDs), light-emitting electrochemical cells (LECs) or luminescence-based sensors and dye-sensitized solar cells (DSSCs) [114-125]. Besides, molecularly-defined copper compounds showed a significant ability to act as catalysts for electrochemical water reduction [126] and oxidation [127-130] and $\mathrm{CO}_{2}$ reduction [131]. In addition, heterogeneous cupric and cuprous oxides have been used as co-catalysts, mainly supported on titania [132-136], or as light-harvesting semiconductors [137-139] for water reduction. Although a 
variety of homo- and hetero-leptic Cu complexes have been developed [121,125,140-146], only recently, two different examples of its successful application as photosensitizers in efficient noble metal-free photocatalytic systems for proton reduction have been reported (Scheme 3) [144,145,147].

\section{Light to Hydrogen: Development and Improvement of an Iron Carbonyl-Based Catalytic System}

Within the frame of our project "Light to Hydrogen", an initial focus laid on the development of efficient catalysts and photosensitizers based on abundant metals in order to substitute rare and expensive noble metals. The realization of a noble metal-free system for photocatalytic hydrogen generation from water was achieved in several steps. In the first step, Beller and coworkers identified simple, inexpensive, readily-available and abundant iron(0) carbonyl complexes to be appropriate WRC applying [(ppy) $\left.{ }_{2} \operatorname{Ir}(\mathrm{bpy})\right] \mathrm{PF}_{6}$ as PS and triethylamine as $\mathrm{SR}$ in $10 \mathrm{~mL}$ of a solution of THF/TEA $/ \mathrm{H}_{2} \mathrm{O}$ $(4 / 1 / 1)$ at $25^{\circ} \mathrm{C}$ under Xe-light irradiation for $3 \mathrm{~h}$. In these experiments, turnover numbers with respect to $\mathrm{Fe}$ of 114,141 and 132, respectively, were achieved with either $\mathrm{Fe}(\mathrm{CO})_{5}, \mathrm{Fe}_{2}(\mathrm{CO})_{9}$ or $\mathrm{Fe}_{3}(\mathrm{CO})_{12}$ as WRC precursors (Scheme 2 and Table 1, Entry 6). Applying the latter under optimized conditions (exclusion of UV light by $420 \mathrm{~nm}$ cut-off filter, ratio Ir-PS:WRC $=1.61: 1$ ) resulted in a maximum $\mathrm{TON}_{\mathrm{Fe}}$ of 400 and deactivation after three hours (Scheme 2) [20]. A significant improvement of the WRC was achieved by the addition of 1.5 equivalents of tris(4-trifluoromethylphenyl)phosphine $\mathrm{P}\left(\mathrm{C}_{6} \mathrm{H}_{4}\left(\mathrm{CF}_{3}\right)\right)_{3}$ or tris[3,5-bis(trifluoromethyl)phenyl]phosphine $\left(\mathrm{P}_{(}\left(\mathrm{C}_{6} \mathrm{H}_{3}\left(\mathrm{CF}_{3}\right)_{2}\right)_{3}\right.$. Applying the latter together with $\mathrm{Fe}_{3}(\mathrm{CO})_{12}$, the in situ-generated WRC achieved a TON of up to 1610 after $24 \mathrm{~h}$ under slightly changed conditions (THF/TEA $/ \mathrm{H}_{2} \mathrm{O}=3 / 2 / 1$, without filter) [76]. Thus, besides the productivity, also the stability of the catalyst system could be increased. Noteworthy, the incident photon to hydrogen efficiency reached $13.4 \%$ at $440 \mathrm{~nm}$. Further improvement was achieved by application of novel monocationic Iridium(III)-photosensitizers with the general formula $\left[\operatorname{Ir}^{\mathrm{III}}\left(\mathrm{C}^{\wedge} \mathrm{N}\right)_{2}\left(\mathrm{~N}^{\wedge} \mathrm{N}\right)\right]^{+}\left(\mathrm{C}^{\wedge} \mathrm{N}\right.$ : mono deprotonated cyclometallating phenyl pyridine, $\mathrm{N}^{\wedge} \mathrm{N}$ : neutral bidentate ligand) and $\left[\operatorname{Ir}(\text { phenyloxazole })_{2}(\mathrm{bpy})\right] \mathrm{PF}_{6}$ (bpy: 2,2'-bipyridine) [21,22]. In this series, [(2-phenylbenz-oxazole $)_{2} \operatorname{Ir}(\mathrm{bpy}) \mathrm{PF}_{6}$ and [(ppy) $)_{2} \operatorname{Ir}\left(6-{ }^{i}\right.$ Pr-bpy) $] \mathrm{PF}_{6}$ (Scheme 3, Table 1, Entry 9) turned out to be the most efficient photosensitizer with $\left[\mathrm{HNEt}_{3}\right]\left[\mathrm{HFe}_{3}(\mathrm{CO})_{11}\right] /$ tris[3,5-bis(trifluoromethyl)phenyl]-phosphine as the water reduction catalyst and triethylamine as the sacrificial reductant. Accordingly, TONs were improved up to 2770 for the Fe-WRC and 4550 for the Ir-PS applying $15 \mu \mathrm{mol}$ and $0.5 \mu \mathrm{mol}$ of the photosensitizer $\left[(\text { ppy })_{2} \operatorname{Ir}\left(6-{ }^{i} \mathrm{Pr}-\mathrm{bpy}\right)\right] \mathrm{PF}_{6}$, respectively. These experiments have been performed under $440-\mathrm{nm}$ irradiation by a Lumatec mercury lamp (Figure 1).

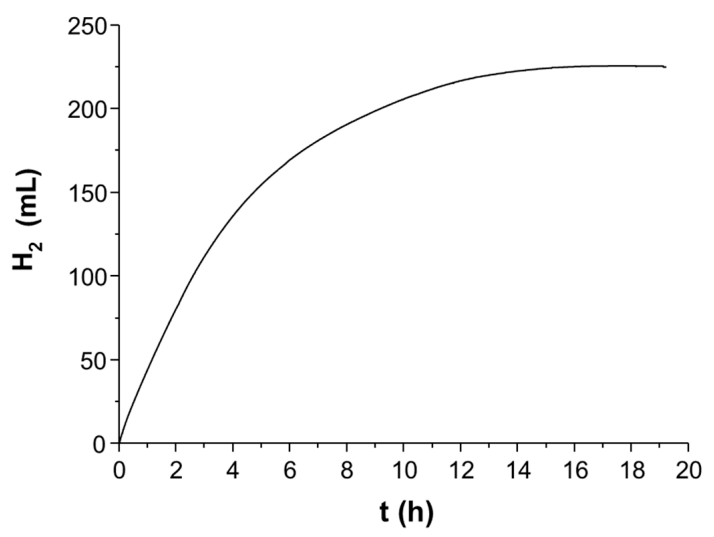

Figure 1. Typical hydrogen evolution curve. Reaction conditions: $3.3 \mu \mathrm{mol}\left[\mathrm{HNEt}_{3}\right]\left[\mathrm{HFe}_{3}(\mathrm{CO})_{11}\right]$, $15.0 \mu \mathrm{mol}$ Ir-PS, $5.0 \mu \mathrm{mol} \mathrm{P}\left(\mathrm{C}_{6} \mathrm{H}_{3}-3,5-\left(\mathrm{CF}_{3}\right)_{2}\right)_{3}$, 440-nm irradiation $1.5 \mathrm{~W}, 20 \mathrm{~mL} \mathrm{THF} / \mathrm{TEA} / \mathrm{H}_{2} \mathrm{O}$ $(3 / 2 / 1), 25^{\circ} \mathrm{C}$. 
The incident photon to hydrogen yield was also increased to $16.4 \%$ applying this system [21]. In order to render light the limiting factor, the lamp performance was decreased to a value of $0.09 \mathrm{~W} \cdot \mathrm{cm}^{-2}$. The number of photons was then determined by chemical actinometer experiments [148]. Obviously, only $46 \%-65 \%$ of the provided photons were available inside the reactor depending on the wavelength and the power. Taking this into consideration, significantly improved quantum yields of up to $48 \%$ at a wavelength of $415 \mathrm{~nm}$ and $41 \%$ at $440 \mathrm{~nm}$, respectively, were achieved (Figure 2).

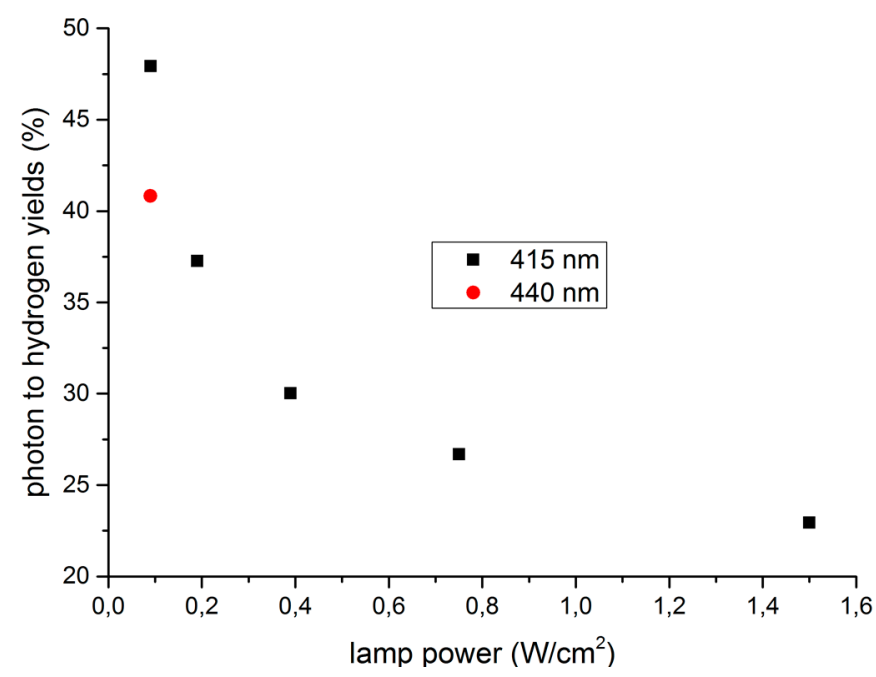

Figure 2. Photon to hydrogen yield determination with dependence on lamp performance and wavelength. Reaction conditions: $3.3 \mu \mathrm{mol} \mathrm{Fe}(\mathrm{CO})_{12} ; 15.0 \mu \mathrm{mol}\left[(\mathrm{ppy})_{2} \operatorname{Ir}(\mathrm{bpy})\right] \mathrm{PF}_{6} ; 5.0 \mu \mathrm{mol}$ ligand (tris[3,5-bis(trifluoromethyl)phenyl]-phosphine); $\left(\mathrm{Fe}_{3}(\mathrm{CO})_{12} / \mathrm{PR}_{3}=1: 1.5\right) ; 10 \mathrm{~mL} \mathrm{THF} / \mathrm{TEA} / \mathrm{H}_{2} 0$ (3:2:1); $25^{\circ} \mathrm{C}, 20 \mathrm{~h}$.

Noteworthy, a noble metal-free water reduction system could be realized applying a copper-based PS instead of the Ir complex. In this respect, we focused on heteroleptic copper complexes with the general formula $\left[\mathrm{Cu}\left(\mathrm{N}^{\wedge} \mathrm{N}\right)\left(\mathrm{P}^{\wedge} \mathrm{P}\right)\right]^{+}(\mathbf{D}$ in Scheme 3, Table 1, Entries 7, 8 and 16). While the absorption and fluorescence spectra of these complexes are similar to those of ruthenium [73,74,149-153] or iridium [21] complexes with polypyridine ligands, the excited state lifetime reaches up to $54 \mu \mathrm{s}$ and, thus, demonstrates that the non-radiative decay is indeed slow and does not interfere with photocatalytic electron transfer processes. A key issue is the improvement of steric and electronic factors in order to get long-lived metal to ligand charge transfer (MLCT) exited states. This was achieved in heteroleptic complexes, especially those bearing the bathocuproine ligand. The methyl groups located at the 2- and 9-position are important to avoid the expansion of the coordination sphere of the metal center [154] and at the same time favor the tetrahedral $\left(T_{\mathrm{d}}\right)$ geometry. Thus, in the MLCT exited state, the flattening to the preferred square planar geometry is significantly reduced $[155,156]$. A number of molecularly-defined Cu-PS has been synthesized based on various combinations of bidentate phosphines and amines. Subsequent tests as PS in the photocatalytic proton reduction in the presence of $\left[\mathrm{Fe}_{3}(\mathrm{CO})_{12}\right]$ as WRC and TEA as SR (THF:TEA: $\left.\mathrm{H}_{2} \mathrm{O}=4: 3: 1\right)$ revealed a TON of up to 1330 for the Cu-PS (Scheme 3) [144,145]. Thus, these noble metal-free systems already achieved productivities in the same order of magnitude as those containing Ru- or Ir-PS.

Finally, the activity of the catalytic proton reduction was improved applying Knölker's iron complexes instead of iron carbonyl complexes. In combination with the mentioned $\mathrm{Cu}-\mathrm{PS}$, the activity was increased up to 15 times (Scheme 2 and Table 1, Entry 16) [157]. Noteworthy, this class of complexes allows for a metal ligand cooperative catalysis, as the oxygen atom at the cyclopentadienyl ring provides a basic center, which can be protonated like the azadithiolate moiety in the [FeFe] hydrogenase, enabling facile heterolytic hydrogen generation [157]. 
Table 1. Selected reported iron-based WRCs (Scheme 2) in photocatalytic hydrogen generation in the presence of photosensitizers (Scheme 3) and sacrificial agents.

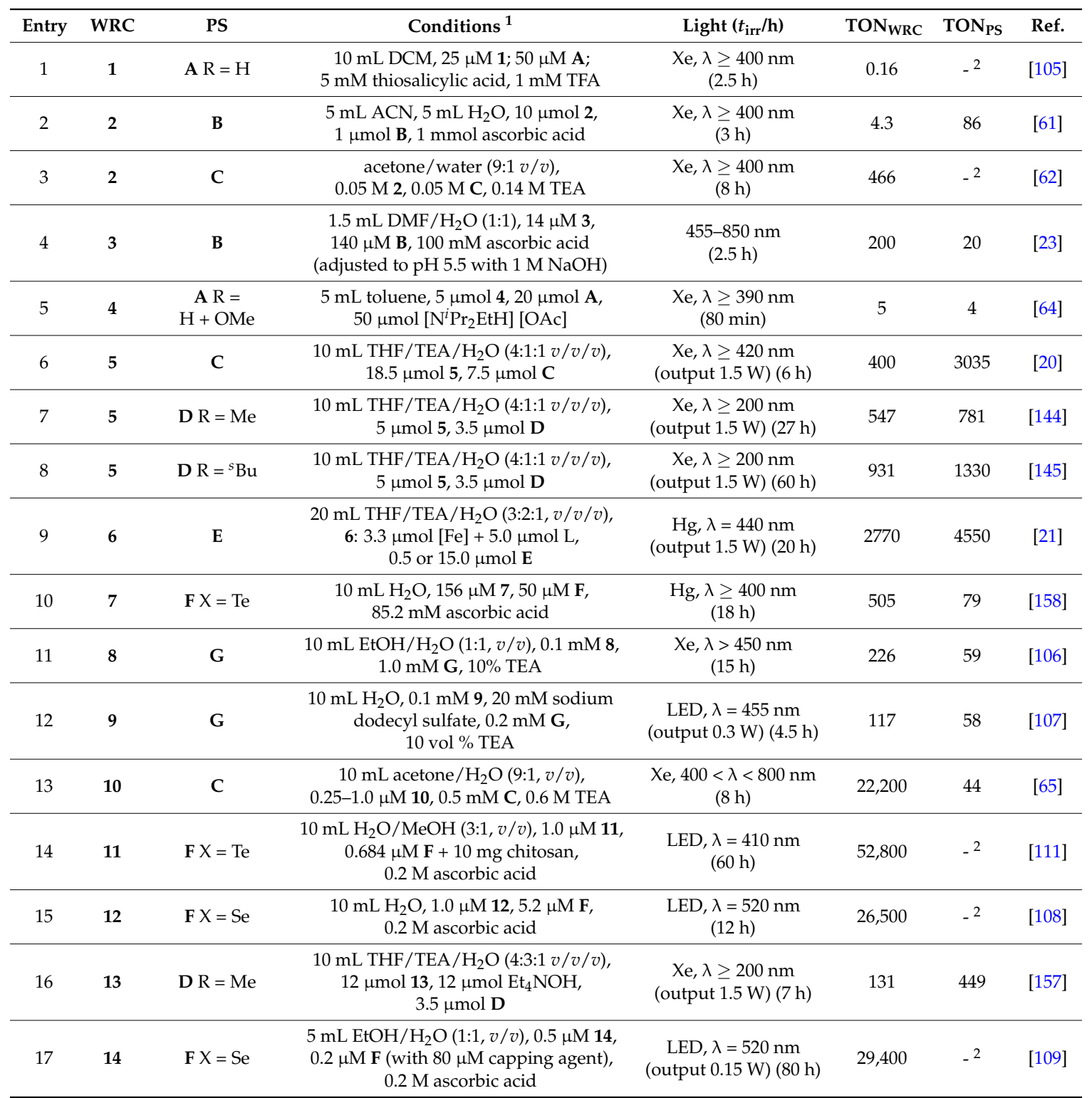

${ }^{1}$ Abbreviations: irr, irradiation; ref., reference; DCM, dichloromethane; TFA, trifluoroacetic acid; ACN, acetonitrile; TEA, triethylamine; DMF, dimethylformamide; THF, tetrahydrofuran. ${ }^{2}$ Not provided.

\section{Improving Mechanistic Understanding by an Approach of Combined Analytical Methods}

The project "Light to Hydrogen" brought together research groups with catalytic, analytical, opto-physical, as well as theoretical expertise, which provided an excellent opportunity to gain deeper mechanistic insights. As a consequence, the Ir-Fe water (proton) reduction system belongs to the most investigated and best understood ones reported so far. Therefore, it will be demonstrated in the following section how a combination of various analytical and theoretical methods clarifies the intricate work mode of the different components including the detection of intermediates. These comprehensive mechanistic studies included Raman, NMR, EPR, in situ, as well as operando FTIR spectroscopy and DFT calculations [159]. In particular, the trimeric complex $\left[\mathrm{HFe}_{3}(\mathrm{CO})_{11}\right]^{-}$was identified as a key intermediate during water reduction by NMR, Raman and in situ FTIR spectroscopy. Comparison with a synthesized [ $\left.\mathrm{HNEt}_{3}\right]\left[\mathrm{HFe}_{3}(\mathrm{CO})_{11}\right]$ proved the assignment of the Raman bands at 223 and $165 \mathrm{~cm}^{-1}$ to this intermediate, as well as the characteristic band pattern in the IR spectrum (bands at 2064, 1999, 
1993, 1975, 1941 and $\left.1748 \mathrm{~cm}^{-1}\right)$. In addition, the monomeric $\left[\mathrm{HFe}(\mathrm{CO})_{4}\right]^{-}$species was detected via in situ IR spectroscopy (bands at 1998, 1908 and $1878 \mathrm{~cm}^{-1}$ ), while EPR spectroscopy enabled the identification of the dimeric $\left[\mathrm{H}_{2} \mathrm{Fe}_{2}(\mathrm{CO})_{7}\right]^{-}(g=2.0432)$ and $\left[\mathrm{Fe}_{2}(\mathrm{CO})_{8}\right]^{\bullet-}(g=2.0385)$ intermediates. The latter two dimeric species are products of a side reaction and constitute intermediates toward $\left[\mathrm{HFe}(\mathrm{CO})_{4}\right]^{-}$(M11), which acts as a resting state $[160,161]$. Deactivation pathways during catalysis are both CO release from the WRC mediated by light irradiation and the decomposition of the Ir-PS especially at high PS/WRC ratios. Then, the released ligand is transferred towards the iron center of the WRC to form $\left[\mathrm{Fe}(\mathrm{CO})_{3}(\mathrm{bpy})\right]$, which was detected by in situ IR spectroscopy. Further, these assumptions are supported by DFT calculations [161,162]. Based on the obtained data, a proposal for the mechanism has been developed (Scheme 4).

In the left cycle, electrons of $\left[(\mathrm{ppy})_{2} \operatorname{Ir}(\mathrm{bpy})\right]^{+}(\mathrm{M} 1)$ are promoted via light irradiation to form the excited $\left[(\mathrm{ppy})_{2} \operatorname{Ir}(\mathrm{bpy})\right]^{+*}(\mathrm{M} 2)$. Time-resolved photoluminescence experiments showed reductive quenching of M2 by TEA, which is the rate-determining step of the overall system. The resulting $\left[(\mathrm{ppy})_{2} \operatorname{Ir}(\mathrm{bpy})\right](\mathrm{M} 3)$ possesses a reduction potential sufficiently high to reduce $\left[\mathrm{Fe}_{3}(\mathrm{CO})_{11}\right]^{\bullet-}(\mathrm{M} 6)$, as well as $\left[\mathrm{HFe}_{3}(\mathrm{CO})_{11}\right]^{-}(\mathrm{M} 7)$ in the right cycle [163]. The sacrificial reductant TEA is converted to oxidized TEA radicals and finally to acetaldehyde after hydrolysis.

The precursor $\mathrm{Fe}_{3}(\mathrm{CO})_{12}$ (M5) is quickly reduced already in the dark by electron transfer from TEA forming the electron-rich 19-electron complex $\left[\mathrm{Fe}_{3}(\mathrm{CO})_{12}\right]^{\bullet-}$. This unstable complex undergoes decarbonylation to the electron-deficient 17 -electron complex $\left[\mathrm{Fe}_{3}(\mathrm{CO})_{11}\right]^{\bullet-}$, as well as $\left[\mathrm{Fe}_{2}(\mathrm{CO})_{8}\right]^{\bullet-}$ and $\mathrm{Fe}(\mathrm{CO})_{5}(\mathrm{M} 6)$. Under light irradiation, reduction of M6 by Ir-PS ${ }^{-}$and subsequent proton transfer result in the formation of the active catalyst $\left[\mathrm{HFe}_{3}(\mathrm{CO})_{11}\right]^{-}(\mathrm{M} 7)$. Subsequently, a second electron transfer is supposed to form $\left[\mathrm{HFe}_{3}(\mathrm{CO})_{11}\right]^{2-}(\mathrm{M} 8)$ followed by a proton transfer to form $\left[\mathrm{H}_{2} \mathrm{Fe}_{3}(\mathrm{CO})_{11}\right]^{-}$(M9). $\mathrm{H}_{2}$ is released from M9, and $\left[\mathrm{Fe}_{3}(\mathrm{CO})_{11}\right]^{2-}$ (M10) is restored after further reduction by the Ir-PS ${ }^{-}$in order to restart the cycle. In parallel, M7 can also be converted into $\left[\mathrm{Fe}_{2}(\mathrm{CO})_{8}\right]^{\bullet-}$ and the resting state $\left[\mathrm{HFe}(\mathrm{CO})_{4}\right]^{-}$(M11) by incorporation of $\mathrm{CO}$ and reduction (vide supra). The reverse reaction from M11 to M7 and reactivation of the WRC are mediated by irradiation $[76,160,161,163]$.

It should be noted that this broad range of methods is unparalleled for a single proton reduction system. The rich chemistry of $\mathrm{Fe}_{3}(\mathrm{CO})_{12}$ in reaction solution in the dark is extended to several more species under illumination in the presence of an Ir-PS with sufficiently high reduction potential in its excited state.

Further, the exact role of added phosphine ligand and its enhancing effect on the TON was of special interest. Recent in situ FTIR experiments reveal the formation of $\left[\mathrm{Fe}_{2}(\mathrm{CO})_{7} \mathrm{P}\left(\mathrm{C}_{6} \mathrm{H}_{4}\left(\mathrm{CF}_{3}\right)\right)_{2}\right]^{-}$ (bands at 2021,1971,1941 and $\left.1922 \mathrm{~cm}^{-1}\right)$, when $\mathrm{P}\left(\mathrm{C}_{6} \mathrm{H}_{4}\left(\mathrm{CF}_{3}\right)\right)_{3}$ was added to the reaction mixture (Figure 3, top). This phosphidodiferrate is more stable than the phosphorus-deficient compounds $\left[\mathrm{HFe}_{3}(\mathrm{CO})_{11}\right]^{-}(\mathrm{M} 7)$ and $\left[\mathrm{HFe}(\mathrm{CO})_{4}\right]^{-}$(M11), and thus, it constitutes the only iron carbonyl complex present in solution after $15 \mathrm{~h}$ of light irradiation (Figure 3, right). At his time, hydrogen generation still continues (Figure 3, left, violet curve), while it stops in the absence of a phosphine ligand (Figure 3, left, grey curve). The spectral assignment of $\left[\mathrm{Fe}_{2}(\mathrm{CO})_{7} \mathrm{P}\left(\mathrm{C}_{6} \mathrm{H}_{4}\left(\mathrm{CF}_{3}\right)\right)_{2}\right]^{-}$is confirmed by DFT calculations and comparison with $\left[\mathrm{Fe}_{2}(\mathrm{CO})_{7} \mathrm{PPh}_{2}\right]^{-}$[164-166]. The latter shows the same IR contributions shifted by $5 \mathrm{~cm}^{-1}$ to lower wavenumbers due to the less electron withdrawing effect of the phenyl group compared to $\mathrm{C}_{6} \mathrm{H}_{4}\left(\mathrm{CF}_{3}\right)$. 

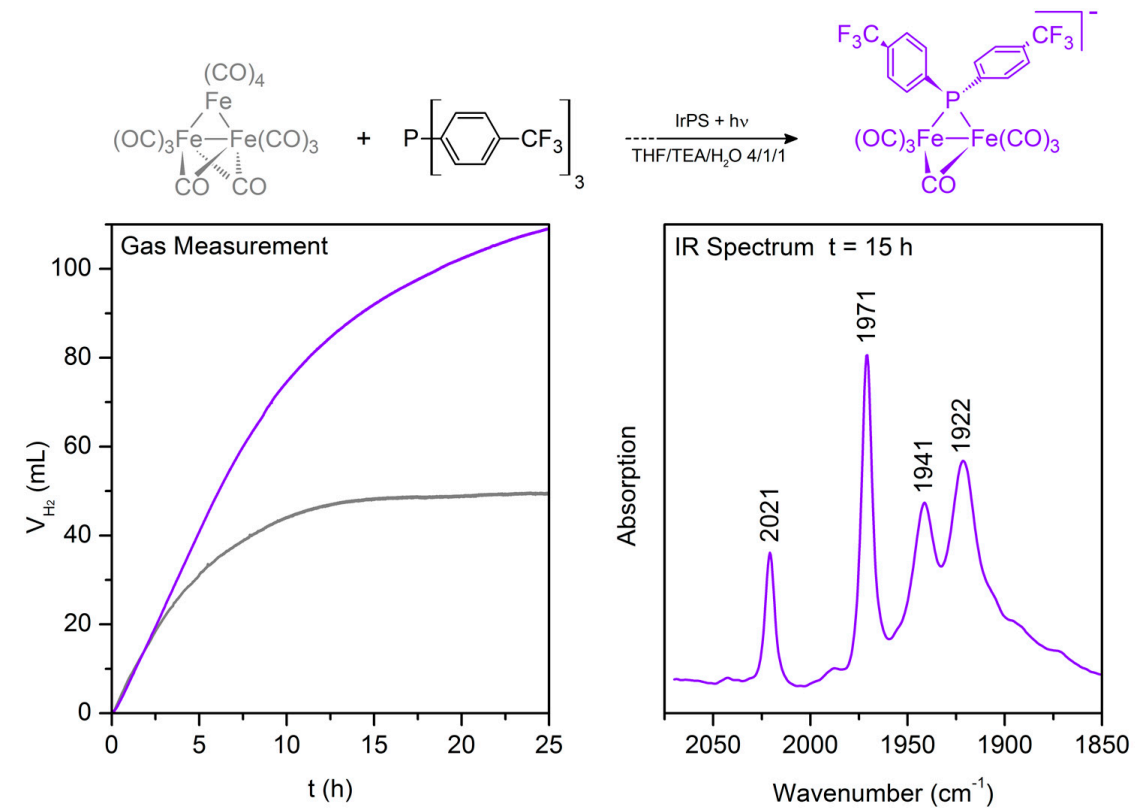

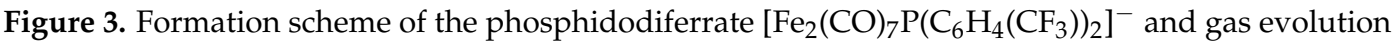
curves with (left, violet curve) and without (left, grey curve) application of $\mathrm{P}\left(\mathrm{C}_{6} \mathrm{H}_{4}\left(\mathrm{CF}_{3}\right)\right)_{3}$. After $15 \mathrm{~h}$ of light irradiation, the phosphidodiferrate is the only WRC present in solution (right, violet spectrum). Reaction conditions: $6.1 \mu \mathrm{mol} \mathrm{Fe}_{3}(\mathrm{CO})_{12} ; 10.0 \mu \mathrm{mol}\left[(\mathrm{ppy})_{2} \operatorname{Ir}(\mathrm{bpy}) \mathrm{PF}_{6} ; 6.1 \mu \mathrm{mol}\right.$ (violet) or $0 \mu \mathrm{mol}$ (grey) $\mathrm{P}\left(-\mathrm{C}_{6} \mathrm{H}_{4}\left(\mathrm{CF}_{3}\right)\right)_{3} ; 20 \mathrm{~mL}$ THF/TEA $/ \mathrm{H}_{2} \mathrm{O}(4: 1: 1) ; 25^{\circ} \mathrm{C} ; 1.5 \mathrm{~W}$ visible light. For experimental details, see $[161,165,166]$.

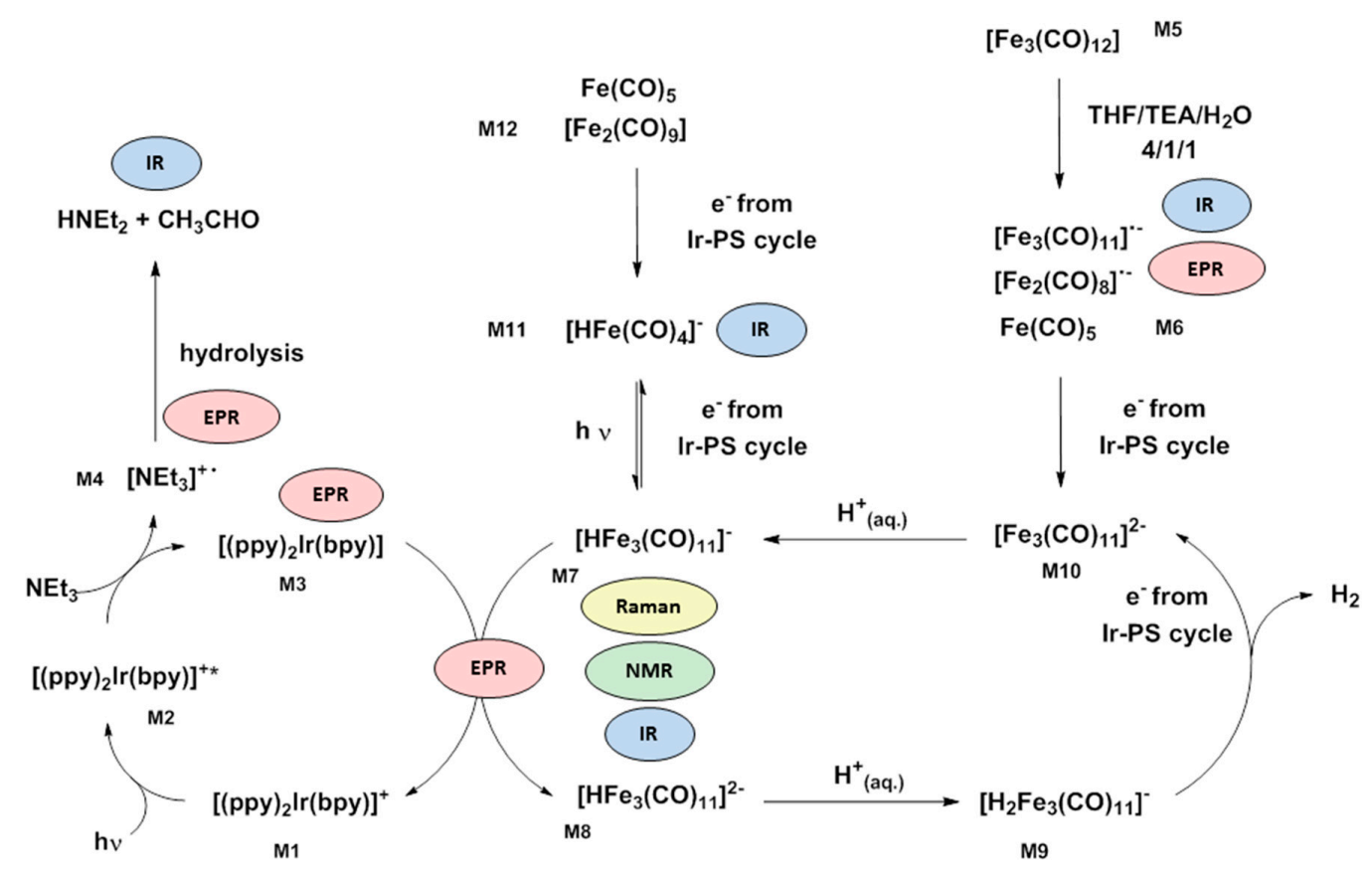

Scheme 4. Proposed catalytic mechanism for light-driven hydrogen generation with $\left[(\mathrm{ppy})_{2} \operatorname{Ir}(\mathrm{bpy})\right] \mathrm{PF}_{6}$ and iron $(0)$ carbonyl precursors. The respective methods of identification are highlighted next to the involved species [76,160-163,165,166].

Interestingly, an analogue phosphidodiferrate constitutes the active WRC in the photocatalytic proton reduction applying also $\mathrm{Cu}-\mathrm{PS}$ and $\mathrm{Fe}_{3}(\mathrm{CO})_{12}$. Mechanistic investigations revealed the existence of an equilibrium between the homo- and hetero-leptic $\mathrm{Cu}$ complexes in solution according to 
Figure $4[141,165]$. Thus, a part of the released xantphos is available as the precursor for the $\mathrm{PR}_{2}$ unit. Besides, the heteroleptic [Cu(bathocuproine)(xantphos)] $\mathrm{PF}_{6}$ was established to present the active PS [166].
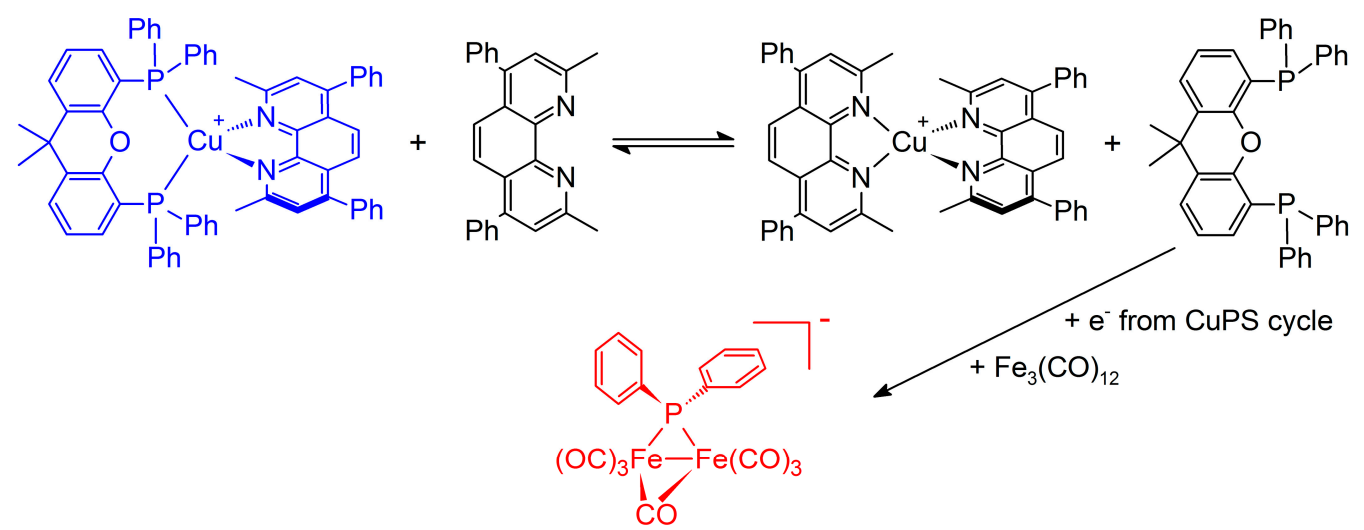

Figure 4. Equilibrium between hetero- and homoleptic $\mathrm{Cu}-\mathrm{PS}$ and the formation of the phosphidodiferrate initiated by reductively-induced xantphos fragmentation. The active Cu-PS and WRC are highlighted in blue and red, respectively.

Taking the equilibrium in Figure 4 into consideration, we successfully developed an in situ method for the synthesis of the organometallic copper complex. Instead of the time-consuming pre-synthesis of molecularly-defined complexes, the application of this method allowed for further optimization of the quantity of ligands leading to improved system efficiency [166].

To investigate the primary steps initiated by the absorption of light for both systems, the Ir-PS/Fe-WRC, as well as the Cu-PS/Fe-WRC, time-resolved UV/Vis absorption and photoluminescence measurements applying a femtosecond pump-probe setup and a streak camera were performed. The UV/Vis absorption spectrum of the Ir-PS $\left[(\text { ppy })_{2} \operatorname{Ir}(\mathrm{bpy})\right]^{+} \mathrm{C}$ results from electronic transitions to ligand centered states and to metal to ligand charge transfer (MLCT) states involving the ppy- and the bpy-ligands at longer wavelengths. After optical excitation ultrafast intersystem crossing (ISC) takes place within the time resolution of the pump-probe experiment of $150 \mathrm{fs}$ [167]. Then, vibrational redistribution and relaxation within the triplet manifold results in the population of the lowest triplet MLCT state on the picosecond timescale. In this state, the excited electron is located on the bpy-ligand, and if the ppy-ligand is originally excited, an ultrafast interligand charge transfer is observed [167].

In the case of the Cu-PS D, ISC takes $7 \mathrm{ps}$ and is preceded by a flattening of the complex structure within the first picosecond [156]. As in the case of the Ir-PS C, the long lifetime of the resulting ${ }^{3} \mathrm{MLCT}$ is a crucial factor for the performance as a sensitizer in photocatalysis.

The electron transfer steps between the photosensitizer and the SR and the WRC were studied by quenching of the photoluminescence from the ${ }^{3} \mathrm{MLCT}$ state (Figure 5). In pure THF, the Ir-PS $\left[(\text { ppy })_{2} \operatorname{Ir}(\mathrm{bpy})\right]^{+} \mathrm{C}$ exhibited a lifetime of $0.37 \mu \mathrm{s}$, which reduces drastically to $15 \mathrm{~ns}$ in the presence of $17 \mathrm{vol} \%$ TEA (Figure 5, left). This is caused by reductive quenching, i.e., an electron transfer from the SR to the metal center of the Ir-PS. The quenching rate can be compared with the calculated diffusion rate. It turns out that the transfer happens only for a small fraction of collisions between TEA and Ir-PS molecules since a specific collision geometry is required for this process [163]. However, the high TEA concentration compensates for the low collision yield and guarantees an effective transfer. At the applied WRC concentrations, the WRC does not significantly contribute to the quenching. Rather, it accepts the electron from the already reduced Ir-PS, and the transfer chain follows a reductive pathway. In the case of the Cu-PS, the situation is different (Figure 5, right). The lifetime of the ${ }^{3} \mathrm{MLCT}$ in THF is $2.9 \mu \mathrm{s}$ at a Cu-PS concentration of $0.35 \mathrm{mM}$. This concentration is also applied in the photocatalytic experiments, but results already in some self-quenching of the PS. If it is reduced to 
$0.02 \mathrm{mM}$, the lifetime doubles to $6.4 \mu \mathrm{s}$ [145]. Adding TEA (17 vol \%) causes a moderate reduction of the luminescence lifetime to $1 \mu \mathrm{s}$, while it strongly decreases down to $50 \mathrm{~ns}$ if the TEA solution also contains $0.5 \mathrm{mM}$ of the WRC. Obviously, the first electron transfer step is here from the Cu-PS to the WRC and is hence associated with an oxidation of the Cu-PS. The reduction of the sensitizer by the SR back to its original configuration occurs as the second step on longer time scales. Accordingly, the electron transfer sequence proceeds via an oxidative route. However, the dominant pathway depends on the specific photocatalytic system, as was shown by the application of Knölker's iron complexes 13 with Cu-PS D, where the reductive pathway is dominant again [157].
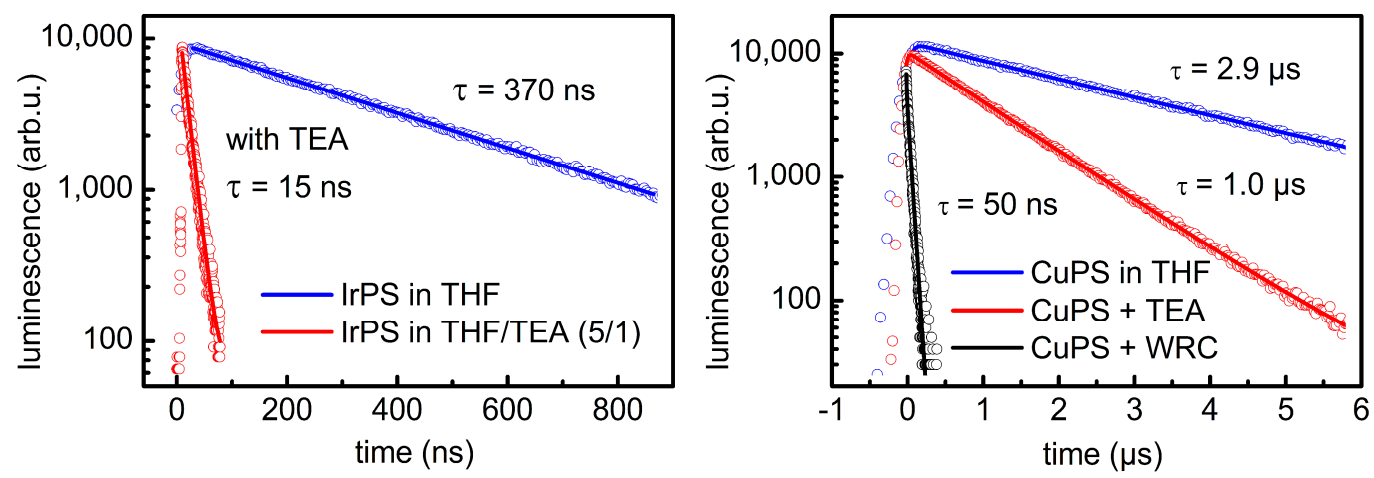

Figure 5. Time resolved photoluminescence and fitted exponential decays of the Ir-PS [(ppy $\left.)_{2} \operatorname{Ir}(\mathrm{bpy})\right]^{+}$ C (left) and the Cu-PS D (right) in THF. Adding 17 volume percent of TEA (red) results in quenching of the luminescence with respect to pure solvent (blue). This effect is particular strong for the Ir-PS, while in the case of the $\mathrm{Cu}-\mathrm{PS}$, the addition of $0.5 \mathrm{mM} \mathrm{WRC}\left[\mathrm{HFe}_{3}(\mathrm{CO})_{11}\right]^{-}$(black) leads to a much faster luminescence decay.

\section{Summary and Outlook}

The productivities of non-noble metal-based WRCs were significantly increased during the last 6-8 years: Thus, the TONs for Ni and Co were improved by four and three orders of magnitude, respectively. The same trend is obvious for iron. While the first successful experiments containing an iron-based WRC gave a TON of 90 in 2006, already five years later, a TON of 2770 was achieved. This trend is continuing, as is demonstrated by the latest records of $>58,000$ turnovers in 2013 . Thus, these WRCs already show a comparable or even better performance compared to previously applied Pt, Rh- or Ru-based WRCs. An additional trend focuses on the development of fully noble metal-free photocatalytic systems in order to substitute expensive Ir and Ru photosensitizers by semiconductors, quantum dots or organic dyes.

In this article, we present the development of a water reduction system containing only base metals. In the first step, a readily-available, simple and inexpensive iron carbonyl compound has been shown to catalyze the proton reduction together with an iridium photosensitizer as the light-harvesting component. The performance of this Fe-WRC was stepwise improved up to a TON of 2770 by the addition of an appropriate phosphine and the development of the more efficient PS [(ppy $)_{2} \operatorname{Ir}\left(6-{ }^{i} \mathrm{Pr}-\mathrm{bpy}\right) \mathrm{PF}_{6}$. The active Fe-WRC was identified to be a phosphidodiferrate $\left[\mathrm{Fe}_{2}(\mathrm{CO})_{7} \mathrm{P}\left(\mathrm{C}_{6} \mathrm{H}_{4}\left(\mathrm{CF}_{3}\right)\right)_{2}\right]^{-}$. Quantum efficiencies of up to $48 \%$ were achieved with these systems applying blue light (415 nm). Finally, we successfully substituted the Ir-PS by molecularly-defined heteroleptic copper photosensitizers of the general formula $\left[\mathrm{Cu}\left(\mathrm{N}^{\wedge} \mathrm{N}\right)\left(\mathrm{P}^{\wedge} \mathrm{P}\right)\right] \mathrm{PF}_{6} . A$ combination of $\mathrm{Fe}_{3}(\mathrm{CO})_{12}$ and $\mathrm{Cu}$-PS in the light-driven water reduction using TEA as the sacrificial reagent resulted in turnover numbers of up to 1330 and a stability of more than two days. Noteworthy, the Cu-PS can even be generated in an in situ method from the precursors during light irradiation, thus avoiding time-consuming synthesis procedures. Besides the catalytic tests, a careful investigation of the reaction mechanism allowed for a deep insight into the reaction mode, including loss channels. 
Spectroscopic studies showed that after optical excitation of the photosensitizer, intramolecular processes result in a fast population of the lowest ${ }^{3} \mathrm{MLCT}$ state, which itself has an intrinsic lifetime of some tenth to several ten microseconds depending on the sensitizer. This long lifetime allows for efficient electron transfer processes from the SR and to the WRC. Whether the reductive or the oxidative pathway prevails depends again on the specific photocatalytic system.

So far, homogeneous catalyst materials have been tested mainly in the water reduction half reaction applying sacrificial reagents as electron donors. This allows for a simplification of the complex system of the overall water splitting and, hence, a more detailed understanding of the basic processes as a prerequisite for improvements. However, a challenge for the next time has to be the application of the developed catalyst systems in photocatalytic or photoelectrocatalytic overall water splitting. This will help avoid the undesired influences of sacrificial reagents onto the catalytic systems, like side reactions, deactivation and changing driving forces.

Acknowledgments: The work has been funded by the Federal Ministry of Education and Research of Germany within the interdisciplinary project "Light to Hydrogen" (L2H), which was a part of the program "Spitzenforschung und Innovation in den Neuen Ländern", the Ministry for Education, Science and Culture of Mecklenburg Western Pomerania and the European Union (Investing in our Future, European Regional Development) within the project PS4H and a joint DFG/NFSC project. We thank all thirteen partners from universities and scientific institutions for fruitful cooperation and their contributions to several aspects of the direct photocatalytic water cleavage. Especially, we thank Felix Gärtner, Esteban Mejía, Shu-Ping Luo, Michael Karnahl, Annette-Enrica Surkus, Daniela Cozzula, Sebastian Losse, Anilkumar Gopinathan, Alastair J. J. Lennox, Mark Jurrat, Dirk Hollmann, Enrico Barsch, Arend Rösel, Elisabeth Oberem, Antje Neubauer, Stefanie Tschierlei, Alexandra Pazidis, Aleksej Friedrich, Sergey I. Bokarev, Olga S. Bokareva and Gilbert Grell. In addition, we acknowledge Anja Kammer, Petra Bartels, Christine Fischer, Wolfgang Baumann and Andreas Koch for their technical and analytical support, as well as Anke Spannenberg for X-ray crystallography.

Author Contributions: Henrik Junge, Nils Rockstroh, Steffen Fischer, Stefan Lochbrunner and Matthias Beller wrote the article. Henrik Junge, Nils Rockstroh and Matthias Beller developed the concept for catalyst development and photocatalytic experiments and supervised these experiments. Nils Rockstroh also partly performed catalyst synthesis and photocatalytic experiments. Steffen Fischer was engaged in the operando FTIR measurements which were supervised by Ralf Ludwig. Stefan Lochbrunner developed the concept and supervised the time resolved photoluminescence spectroscopy experiments. Angelika Brückner developed the concept and supervised the EPR and Raman investigation. Oliver Kühn supervised the theoretical calculations and discussions.

Conflicts of Interest: The authors declare no conflict of interest.

\section{References}

1. Armaroli, N.; Balzani, V. The Future of Energy Supply: Challenges and Opportunities. Angew. Chem. Int. Ed. 2007, 46, 52-66. [CrossRef] [PubMed]

2. Schiermeier, Q.; Tollefson, J.; Scully, T.; Witze, A.; Morton, O. Electricity without Carbon. Nature 2008, 454, 816-823. [CrossRef] [PubMed]

3. Jacobson, M.Z. Review of solutions to global warming, air pollution, and energy security. Energy Environ. Sci. 2009, 2, 148-173. [CrossRef]

4. Armaroli, N.; Balzani, V. Energy for a Sustainable World, 1st ed.; Wiley-VCH: Weinheim, Germany, 2011.

5. Arakawa, H.; Aresta, M.; Armor, J.N.; Barteau, M.A.; Beckman, E.J.; Bell, A.T.; Bercaw, J.E.; Creutz, C.; Dinjus, E.; Dixon, D.A.; et al. Catalysis Research of Relevance to Carbon Management: Progress, Challenges, and Opportunities. Chem. Rev. 2001, 101, 953-996. [CrossRef] [PubMed]

6. Lewis, N.S.; Nocera, D.G. Powering the planet: Chemical challenges in solar energy utilization. Proc. Natl. Acad. Sci. USA 2006, 103, 15729-15735. [CrossRef] [PubMed]

7. Centi, G.; Perathoner, S. Towards Solar Fuels from Water and $\mathrm{CO}_{2}$. ChemSusChem 2010, 3, 195-208. [CrossRef] [PubMed]

8. Balzani, V.; Credi, A.; Venturi, M. Photochemical Conversion of Solar Energy. ChemSusChem 2008, 1, 26-58. [CrossRef] [PubMed]

9. Lubitz, W.; Reijerse, E.J.; Messinger, J. Solar water-splitting into $\mathrm{H}_{2}$ and $\mathrm{O}_{2}$ : Design principles of photosystem II and hydrogenases. Energy Environ. Sci. 2008, 1, 15-31. [CrossRef]

10. Armaroli, N.; Balzani, V. The Hydrogen Issue. ChemSusChem 2011, 4, 21-36. [CrossRef] [PubMed] 
11. Esswein, A.J.; Nocera, D.G. Hydrogen Production by Molecular Photocatalysis. Chem. Rev. 2007, 107, 4022-4047. [CrossRef] [PubMed]

12. Osterloh, F.E. Inorganic Materials as Catalysts for Photochemical Splitting of Water. Chem. Mater. 2008, 20, 35-54. [CrossRef]

13. Nocera, D.G. Personalized Energy: The Home as a Solar Power Station and Solar Gas Station. ChemSusChem 2009, 2, 387-390. [CrossRef] [PubMed]

14. Kudo, A.; Miseki, Y. Heterogeneous photocatalyst materials for water splitting. Chem. Soc. Rev. 2009, 38, 253-278. [CrossRef] [PubMed]

15. Yerga, R.M.N.; Galván, M.C.Á.; del Valle, F.; de la Mano, J.A.V.; Fierro, J.L.G. Water Splitting on Semiconductor Catalysts under Visible-Light Irradiation. ChemSusChem 2009, 2, 471-485. [CrossRef] [PubMed]

16. Chen, X.; Shen, S.; Guo, L.; Mao, S.S. Semiconductor-based Photocatalytic Hydrogen Generation. Chem. Rev. 2010, 110, 6503-6570. [CrossRef] [PubMed]

17. Schulz, M.; Karnahl, M.; Schwalbe, M.; Vos, J.G. The role of the bridging ligand in photocatalytic supramolecular assemblies for the reduction of protons and carbon dioxide. Coord. Chem. Rev. 2012, 256, 1682-1705. [CrossRef]

18. Blankenship, R.E.; Tiede, D.M.; Barber, J.; Brudvig, G.W.; Fleming, G.; Ghirardi, M.; Gunner, M.R.; Junge, W.; Kramer, D.M.; Melis, A.; et al. Comparing Photosynthetic and Photovoltaic Efficiencies and Recognizing the Potential for Improvement. Science 2011, 332, 805-809. [CrossRef] [PubMed]

19. Bensaid, S.; Centi, G.; Garrone, E.; Perathoner, S.; Saracco, G. Towards Artificial Leaves for Solar Hydrogen and Fuels from Carbon Dioxide. ChemSusChem 2012, 5, 500-521. [CrossRef] [PubMed]

20. Gärtner, F.; Sundararaju, B.; Surkus, A.-E.; Boddien, A.; Loges, B.; Junge, H.; Dixneuf, P.H.; Beller, M. Light-Driven Hydrogen Generation: Efficient Iron-Based Water Reduction Catalysts. Angew. Chem. Int. Ed. 2009, 48, 9962-9965. [CrossRef] [PubMed]

21. Gärtner, F.; Cozzula, D.; Losse, S.; Boddien, A.; Anilkumar, G.; Junge, H.; Schulz, T.; Marquet, N.; Spannenberg, A.; Gladiali, S.; et al. Synthesis, Characterisation and Application of Iridium(III) Photosensitisers for Catalytic Water Reduction. Chem. Eur. J. 2011, 17, 6998-7006. [CrossRef] [PubMed]

22. Gärtner, F.; Denurra, S.; Losse, S.; Neubauer, A.; Boddien, A.; Anilkumar, G.; Spannenberg, A.; Junge, H.; Lochbrunner, S.; Blug, M.; et al. Synthesis and Characterization of New Iridium Photosensitizers for Catalytic Hydrogen Generation from Water. Chem. Eur. J. 2012, 18, 3220-3225. [CrossRef] [PubMed]

23. Streich, D.; Astuti, Y.; Orlandi, M.; Schwartz, L.; Lomoth, R.; Hammarström, L.; Ott, S. High-Turnover Photochemical Hydrogen Production Catalyzed by a Model Complex of the [FeFe]-Hydrogenase Active Site. Chem. Eur. J. 2010, 16, 60-63. [CrossRef] [PubMed]

24. Zhang, P.; Wang, M.; Li, C.; Li, X.; Dong, J.; Sun, L. Photochemical $\mathrm{H}_{2}$ production with noble-metal-free molecular devices comprising a porphyrin photosensitizer and a cobaloxime catalyst. Chem. Commun. 2010, 46, 8806-8808. [CrossRef] [PubMed]

25. Lazarides, T.; Delor, M.; Sazanovich, I.V.; McCormick, T.M.; Georgakaki, I.; Charalambidis, G.; Weinstein, J.A.; Coutsolelos, A.G. Photocatalytic hydrogen production from a noble metal free system based on a water soluble porphyrin derivative and a cobaloxime catalyst. Chem. Commun. 2014, 50, 521-523. [CrossRef] [PubMed]

26. Luca, O.R.; Blakemore, J.D.; Konezny, S.J.; Praetorius, J.M.; Schmeier, T.J.; Hunsinger, G.B.; Batista, V.S.; Brudvig, G.W.; Hazary, N.; Crabtree, R.H. Organometallic Ni Pincer Complexes for the Electrocatalytic Production of Hydrogen. Inorg. Chem. 2012, 51, 8704-8709. [CrossRef] [PubMed]

27. Sala, X.; Romero, I.; Rodriguez, M.; Escriche, L.; Llobet, A. Molecular Catalysts that Oxidize Water to Dioxygen. Angew. Chem. Int. Ed. 2009, 48, 2842-2852. [CrossRef] [PubMed]

28. Limburg, B.; Bouwman, E.; Bonnet, S. Molecular water oxidation catalysts based on transition metals and their decomposition pathways. Coord. Chem. Rev. 2012, 256, 1451-1467. [CrossRef]

29. Young, K.J.; Martini, L.A.; Milot, R.L.; Snoeberger, R.C., III; Batista, V.S.; Schmuttenmaer, C.A.; Crabtree, R.H.; Brudvig, G.W. Light-driven water oxidation for solar fuels. Coord. Chem. Rev. 2012, 256, 2503-2520. [CrossRef] [PubMed]

30. Du, P.; Eisenberg, R. Catalysts made of earth-abundant elements (Co, Ni, Fe) for water splitting: Recent progress and future challenges. Energy Environ. Sci. 2012, 5, 6012-6021. [CrossRef] 
31. Eckenhoff, W.T.; Eisenberg, R. Molecular systems for light driven hydrogen production. Dalton Trans. 2012, 41, 13004-13021. [CrossRef] [PubMed]

32. Wang, M.; Chen, L.; Sun, L. Recent progress in electrochemical hydrogen production with earth-abundant metal complexes as catalysts. Energy Environ. Sci. 2012, 5, 6763-6778. [CrossRef]

33. Wang, M.; Sun, L. Hydrogen Production by Noble-Metal-Free Molecular Catalysts and Related Nanomaterials. ChemSusChem 2010, 3, 551-554. [CrossRef] [PubMed]

34. Losse, S.; Vos, J.G.; Rau, S. Catalytic hydrogen production at cobalt centres. Coord. Chem. Rev. 2010, 254, 2492-2504. [CrossRef]

35. Artero, V.; Chavarot-Kerlidou, M.; Fontecave, M. Splitting Water with Cobalt. Angew. Chem. Int. Ed. 2011, 50, 7238-7266. [CrossRef] [PubMed]

36. Bachmann, C.; Guttentag, M.; Spingler, B.; Alberto, R. 3d Element Complexes of Pentadentate Bipyridine-Pyridine-Based Ligand Scaffolds: Structures and Photocatalytic Activities. Inorg. Chem. 2013, 52, 6055-6061. [CrossRef] [PubMed]

37. Mc Laughlin, M.P.; Mc Cormick, T.M.; Eisenberg, R.; Holland, P.L. A stable molecular nickel catalyst for the homogeneous photogeneration of hydrogen in aqueous solution. Chem. Commun. 2011, 47, 7989-7991. [CrossRef] [PubMed]

38. Han, Z.; McNamara, W.R.; Eum, M.E.; Holland, P.L.; Eisenberg, R. A Nickel Thiolate Catalyst for the Long-Lived Photocatalytic Production of Hydrogen in a Noble-Metal-Free System. Angew. Chem. Int. Ed. 2012, 51, 1667-1670. [CrossRef] [PubMed]

39. Das, A.; Han, Z.; Brennessel, W.W.; Holland, P.L.; Eisenberg, R. Nickel Complexes for Robust Light-Driven and Electrocatalytic Hydrogen Production from Water. ACS Catal. 2015, 5, 1397-1406. [CrossRef]

40. Han, Z.; Shen, L.; Brennessel, W.W.; Holland, P.L.; Eisenberg, R. Nickel Pyridinethiolate Complexes as Catalysts for the Light-Driven Production of Hydrogen from Aqueous Solutions in Noble-Metal-Free Systems. J. Am. Chem. Soc. 2013, 135, 14659-14669. [CrossRef] [PubMed]

41. Wilson, A.D.; Newell, R.H.; McNevin, M.J.; Muckermann, J.T.; DuBois, M.R.; DuBois, D.L. Hydrogen Oxidation and Production Using Nickel-Based Molecular Catalysts with Positioned Proton Relays. J. Am. Chem. Soc. 2006, 128, 358-366. [CrossRef] [PubMed]

42. Helm, M.L.; Stewart, M.P.; Bullock, R.M.; DuBois, M.R.; DuBois, D.L. A Synthetic Nickel Electrocatalyst with a Turnover Frequency Above $100,000 \mathrm{~s}^{-1}$ for $\mathrm{H}_{2}$ Production. Science 2011, 333, 863-866. [CrossRef] [PubMed]

43. Wang, C.; Cao, S.; Fu, W.-F. A stable dual-functional system of visible-light-driven Ni(II) reduction to a nickel nanoparticle catalyst and robust in situ hydrogen production. Chem. Commun. 2013, 49, 11251-11253. [CrossRef] [PubMed]

44. Wang, C.J.; Cao, S.; Qin, B.; Zhang, C.; Li, T.-T.; Fu, W.-F. Photoreduction of Iron(III) to Iron(0) Nanoparticles for Simultaneous Hydrogen Evolution in Aqueous Solution. ChemSusChem 2014, 7, 1924-1933. [CrossRef] [PubMed]

45. Brooks, A.C.; Basore, K.; Bernhard, S. Organocatalytic photoreduction of Zn(II) to zinc metal. Chem Commun. 2014, 50, 5196-5199. [CrossRef] [PubMed]

46. Junge, H.; Codolà, Z.; Kammer, A.; Rockstroh, N.; Karnahl, M.; Luo, S.-P.; Pohl, M.-M.; Radnik, J.; Gatla, S.; Wohlrab, S.; et al. Copper-based water reduction catalysts for efficient light-drivenhydrogen generation. J. Mol. Catal. A Chem. 2014, 395, 449-456. [CrossRef]

47. Fontecilla-Camps, J.C.; Volbeda, A.; Cavazza, C.; Nicolet, Y. Structure/Function Relationships of [NiFe]- and [FeFe]-Hydrogenases. Chem. Rev. 2007, 107, 4273-4303. [CrossRef] [PubMed]

48. Vignais, P.M.; Billoud, B. Occurrence, Classification, and Biological Function of Hydrogenases: An Overview. Chem. Rev. 2007, 107, 4206-4272. [CrossRef] [PubMed]

49. Lubitz, W.; Ogata, H.; Rüdiger, O.; Reijerse, E. Hydrogenases. Chem. Rev. 2014, 114, 4081-4148. [CrossRef] [PubMed]

50. Frey, M. Hydrogenases: Hydrogen-Activating Enzymes. ChemBioChem 2002, 3, 153-160. [CrossRef]

51. Silakov, A.; Wenk, B.; Reijerse, E.; Lubitz, W. ${ }^{14} \mathrm{~N}$ HYSCORE investigation of the H-cluster of [FeFe] hydrogenase: Evidence for a nitrogen in the dithiol bridge. Phys. Chem. Chem. Phys. 2009, 11, 6592-6599. [CrossRef] [PubMed] 
52. Erdem, Ö.F.; Schwartz, L.; Stein, M.; Silakov, A.; Kaur-Ghumaan, S.; Huang, P.; Ott, S.; Reijerse, E.J.; Lubitz, W. A Model of the [FeFe] Hydrogenase Active Site with a Biologically Relevant Azadithiolate Bridge: A Spectroscopic and Theoretical Investigation. Angew. Chem. Int. Ed. 2011, 50, 1439-1443. [CrossRef] [PubMed]

53. Liu, T.; Wang, X.; Hoffmann, C.; DuBois, D.L.; Bullock, R.M. Heterolytic Cleavage of Hydrogen by an Iron Hydrogenase Model: An Fe-H..H-N Dihydrogen Bond Characterized by Neutron Diffraction. Angew. Chem. Int. Ed. 2014, 53, 5300-5304. [CrossRef] [PubMed]

54. Zell, T.; Ben-David, Y.; Milstein, D. Unprecedented Iron-Catalyzed Ester Hydrogenation. Mild, Selective, and Efficient Hydrogenation of Trifluoroacetic Esters to Alcohols Catalyzed by an Iron Pincer Complex. Angew. Chem. Int. Ed. 2014, 53, 4685-4689. [CrossRef] [PubMed]

55. Langer, R.; Iron, M.A.; Konstantinovski, L.; Diskin-Posner, Y.; Leitus, G.; Ben-David, Y.; Milstein, D. Iron Borohydride Pincer Complexes for the Efficient Hydrogenation of Ketones under Mild, Base-Free Conditions: Synthesis and Mechanistic Insight. Chem. Eur. J. 2012, 18, 7196-7209. [CrossRef] [PubMed]

56. Alberico, E.; Sponholz, P.; Cordes, C.; Nielsen, M.; Drexler, H.-D.; Baumann, W.; Junge, H.; Beller, M. Selective Hydrogen Production from Methanol with a Defined Iron Pincer Catalyst under Mild Conditions. Angew. Chem. Int. Ed. 2013, 52, 14162-14166. [CrossRef] [PubMed]

57. Werkmeister, S.; Junge, K.; Wendt, B.; Alberico, E.; Jiao, H.; Baumann, W.; Junge, H.; Gallou, F.; Beller, M. Hydrogenation of Esters to Alcohols with a Well-Defined Iron Complex. Angew. Chem. Int. Ed. 2014, 53, 8722-8726. [CrossRef] [PubMed]

58. Bornschein, C.; Werkmeister, S.; Wendt, B.; Jiao, H.; Alberico, E.; Baumann, W.; Junge, H.; Junge, K.; Beller, M. Mild and selective hydrogenation of aromatic and aliphatic (di)nitiles with a well-defined iron pincer complex. Nat. Commun. 2014, 5, 4111. [CrossRef] [PubMed]

59. Lagaditis, P.O.; Sues, P.E.; Sonnenberg, J.F.; Wan, K.Y.; Lough, A.J.; Morris, R.H. Iron(II) Complexes Containing Unsymmetrical P-N-P' Pincer Ligands for the Catalytic Asymmetric Hydrogenation of Ketones and Imines. J. Am. Chem. Soc. 2014, 136, 1367-1380. [CrossRef] [PubMed]

60. Chakraborty, S.; Lagaditis, P.O.; Förster, M.; Bielinsky, B.A.; Hazari, N.; Holthausen, M.C.; Joones, W.D.; Schneider, S. Well-Defined Iron Catalysts for the Acceptorless Reversible Dehydrogenation-Hydrogenation of Alcohols and Ketones. ACS Catal. 2014, 4, 3994-4003. [CrossRef]

61. Na, Y.; Wang, M.; Pan, J.; Zhang, P.; Åkermark, B.; Sun, L. Visible Light-Driven Electron Transfer and Hydrogen Generation Catalyzed by Bioinspired [2Fe2S] Complexes. Inorg. Chem. 2008, 47, 2805-2810. [CrossRef] [PubMed]

62. Zhang, P.; Wang, M.; Na, Y.; Li, X.; Jiang, Y.; Sun, L. Homogeneous photocatalytic production of hydrogen from water by a bioinspired [Fe2S2] catalyst with high turnover numbers. Dalton Trans. 2010, 39, 1204-1206. [CrossRef] [PubMed]

63. Lomoth, R.; Ott, S. Introducing a dark reaction to photochemistry: Photocatalytic hydrogen from [FeFe] hydrogenase active site model complexes. Dalton Trans. 2009, 9952-9959. [CrossRef] [PubMed]

64. Kluwer, A.M.; Kapre, R.; Hartl, F.; Lutz, M.; Spek, A.L.; Brouwer, A.M.; van Leeuwen, P.W.N.M.; Reek, J.N.H. Self-assembled biomimetic [2Fe2S]-hydrogenase-based photocatalyst for molecular hydrogen evolution. Proc. Natl. Acad. Sci. USA 2009, 106, 10460-10465. [CrossRef] [PubMed]

65. Yu, T.; Zeng, Y.; Chen, J.; Li, Y.-Y.; Yang, G.; Li, Y. Exceptional Dendrimer-Based Mimics of Diiron Hydrogenase for the Photochemical Production of Hydrogen. Angew. Chem. Int. Ed. 2013, 52, 5631-5635. [CrossRef] [PubMed]

66. Pullen, S.; Fei, H.; Orthaber, A.; Cohen, S.M.; Ott, S. Enhanced Photochemical Hydrogen Production by a Molecular Diiron Catalyst Incorporated into a Metal-Organic Framework. J. Am. Chem. Soc. 2013, 135, 16997-17003. [CrossRef] [PubMed]

67. Onoda, A.; Kihara, Y.; Fukumoto, K.; Sano, Y.; Hayashi, T. Photoinduced Hydrogen Evolution Catalyzed by a Synthetic Diiron Dithiolate Complex Embedded within a Protein Matrix. ACS Catal. 2014, 4, 2645-2648. [CrossRef]

68. Lehn, J.-M.; Sauvage, J.-P. Chemical storage of light energy. Catalytic generation of hydrogen by visible light or sunlight. Irradiation of neutral aqueous solutions. Nouv. J. Chim. 1977, 1, 449-451.

69. Kalyanasundaram, K.; Kiwi, J.; Grätzel, M. Hydrogen Evolution from Water by Visible Light, a Homogeneous Three Component Test System for Redox Catalysis. Helv. Chim. Acta 1978, 61, 2720-2730. [CrossRef] 
70. Kiwi, J.; Grätzel, M. Dynamics of Light-Induced Redox Processes in Microemulsion Systems. J. Am. Chem. Soc. 1978, 100, 6314-6320. [CrossRef]

71. Moradpour, A.; Amouyal, E.; Keller, P.; Kagan, H. Hydrogen production by visible light irradiation of aqueous solutions of tris(2,2'-bipyridine)ruthenium(2+). Nouv. J. Chim. 1978, 2, 547-549.

72. Kirch, M.; Lehn, J.-M.; Sauvage, J.-P. Hydrogen Generation by Visible Light Irradiation of Aqueous Solutions of Metal Complexes. An Approach to the Photochemical Conversion and Storage of Solar Energy. Helv. Chim. Acta 1979, 62, 1345-1384. [CrossRef]

73. Abbotto, A.; Manfredi, N. Electron-rich heteroaromatic conjugated polypyridine ruthenium sensitizers for dye-sensitized solar cells. Dalton Trans. 2011, 40, 12421-12438. [CrossRef] [PubMed]

74. Vougioukalakis, G.C.; Philippopoulos, A.I.; Stergiopoulos, T.; Falaras, P. Contributions to the development of ruthenium-based sensitizers for dye-sensitized solar cells. Coord. Chem. Rev. 2011, 255, 2602-2621. [CrossRef]

75. DiSalle, B.F.; Bernhard, S. Orchestrated Photocatalytic Water Reduction Using Surface-Adsorbing Iridium Photosensitizers. J. Am. Chem. Soc. 2011, 133, 11819-11821. [CrossRef] [PubMed]

76. Gärtner, F.; Boddien, A.; Barsch, E.; Fumino, K.; Losse, S.; Junge, H.; Hollmann, D.; Brückner, A.; Ludwig, R.; Beller, M. Photocatalytic Hydrogen Generation from Water with Iron Carbonyl Phosphine Complexes: Improved Water Reduction Catalysts and Mechanistic Insights. Chem. Eur. J. 2011, 17, 6425-6436. [CrossRef] [PubMed]

77. Du, P.W.; Knowles, K.; Eisenberg, R. A Homogeneous System for the Photogeneration of Hydrogen from Water Based on a Platinum(II) Terpyridyl Acetylide Chromophore and a Molecular Cobalt Catalyst. J. Am. Chem. Soc. 2008, 130, 12576-12577. [CrossRef] [PubMed]

78. Okazaki, R.; Masaoka, S.; Sakai, K. Photo-hydrogen-evolving activity of chloro(terpyridine)platinum(II): A single-component molecular photocatalyst. Dalton Trans. 2009, 6127-6133. [CrossRef] [PubMed]

79. Wang, W.-G.; Wang, F.; Wang, H.-Y.; Tung, C.-H.; Wu, L.-Z. Electron transfer and hydrogen generation from a molecular dyad: Platinum(II) alkynyl complex anchored to [FeFe] hydrogenase subsite mimic. Dalton Trans. 2012, 41, 2420-2426. [CrossRef] [PubMed]

80. Jiang, W.N.; Liu, J.H.; Li, C. Photochemical hydrogen evolution catalyzed by trimetallic [Re-Fe] complexes. Inorg. Chem. Commun. 2012, 16, 81-85. [CrossRef]

81. Probst, B.; Kolano, C.; Hamm, P.; Alberto, R. An Efficient Homogeneous Intermolecular Rhenium-Based Photocatalytic System for the Production of $\mathrm{H}_{2}$. Inorg. Chem. 2009, 48, 1836-1843. [CrossRef] [PubMed]

82. Takeda, H.; Koike, K.; Morimoto, T.; Inumaru, H.; Ishitani, O. Photochemistry and photocatalysis of rhenium(I) diimine complexes. Adv. Inorg. Chem. 2011, 63, 137-186.

83. Wang, H.-Y.; Wang, W.-G.; Si, G.; Wang, F.; Tung, C.-H.; Wu, L.-Z. Photocatalytic Hydrogen Evolution from Rhenium(I) Complexes to [FeFe] Hydrogenase Mimics in Aqueous SDS Micellar Systems: A Biomimetic Pathway. Langmuir 2010, 26, 9766-9771. [CrossRef] [PubMed]

84. Probst, B.; Guttentag, M.; Rodenberg, A.; Hamm, P.; Alberto, R. Photocatalytic $\mathrm{H}_{2}$ Production from Water with Rhenium and Cobalt Complexes. Inorg. Chem. 2011, 50, 3404-3412. [CrossRef] [PubMed]

85. Probst, B.; Rodenberg, A.; Guttentag, M.; Hamm, P.; Alberto, R. A Highly Stable Rhenium-Cobalt System for Photocatalytic $\mathrm{H}_{2}$ Production: Unraveling the Performance-Limiting Steps. Inorg. Chem. 2010, 49, 6453-6460. [CrossRef] [PubMed]

86. Harlang, T.C.B.; Liu, Y.; Gordivska, O.; Fredin, L.A.; Ponseca, C.S., Jr.; Huang, P.; Chabera, P.; Kjaer, K.S.; Mateos, H.; Uhlig, J.; et al. Iron sensitizer converts light to electrons with 92\% yield. Nat. Chem. 2015, 7, 883-889. [CrossRef] [PubMed]

87. Poddutoori, P.; Co, D.T.; Samuel, A.P.S.; Kim, C.H.; Vagnini, M.T.; Wasielewski, M.R. Photoinitiated multistep charge separation in ferrocene-zinc porphyrin-diiron hydrogenase model complex triads. Energy Environ. Sci. 2011, 4, 2441-2450. [CrossRef]

88. Yamaguchi, H.; Onji, T.; Ohara, H.; Ikeda, N.; Harada, A. Photoinduced Hydrogen-Evolution System with an Antibody-Porphyrin Complex as a Photosensitizer. Bull. Chem. Soc. Jpn. 2009, 82, 1341-1346. [CrossRef]

89. Zorlu, Y.; Dumoulin, F.; Durmus, M.; Ahsen, V. Comparative studies of photophysical and photochemical properties of solketal substituted platinum(II) and zinc(II) phthalocyanine sets. Tetrahedron 2010, 66, 3248-3258. [CrossRef] 
90. Amao, Y.; Aoki, K. Artificial Photosynthesis System Using Mg Chlorophyll- $a$ Conjugated Nanocrystalline $\mathrm{TiO}_{2}$ Film Electrode via the Axial Imidazole-4-Acetic Acid Ligand. J. Biobased Mater. Bioenergy 2008, 2, 51-56. [CrossRef]

91. Amao, Y.; Hirakawa, T. Hydrolysis of a mixture of saccharides by cellulase from Aspergillus niger and its application for visible-light-induced hydrogen gas production system using Mg chlorophyll- $a$ and platinum nanoparticles. Int. J. Hydrogen Energy 2010, 35, 6624-6628. [CrossRef]

92. Amao, Y.; Hirakawa, T.; Himeshima, N. Photoinduced biohydrogen production from saccharide mixture with the photosensitization of $\mathrm{Mg}$ chlorophyll $a$ from green plant. Catal. Commun. 2008, 9, 131-134. [CrossRef]

93. Amao, Y.; Maki, Y.; Fuchino, Y. Photoinduced Hydrogen Production with Artificial Photosynthesis System Based on Carotenoid-Chlorophyll Conjugated Micelles. J. Phys. Chem. C 2009, 113, 16811-16815. [CrossRef]

94. Tomonou, Y.; Amao, Y. Visible and near-IR light induced biohydrogen production using the system containing Mg chlorophyll-a from Spirulina and colloidal platinum. Biometals 2003, 16, 419-424. [CrossRef] [PubMed]

95. Gimbert-Suriñach, C.; Albero, J.; Stoll, T.; Fortage, J.; Collomb, M.-N.; Deronzier, A.; Palomares, E.; Llobet, A. Efficient and Limiting Reactions in Aqueous Light-Induced Hydrogen Evolution Systems using Molecular Catalysts and Quantum Dots. J. Am. Chem. Soc. 2014, 136, 7655-7661. [CrossRef] [PubMed]

96. Martindale, B.C.M.; Hutton, G.A.M.; Caputo, C.A.; Reisner, E. Solar Hydrogen Production Using Carbon Quantum Dots and a Molecular Nickel Catalyst. J. Am. Chem. Soc. 2015, 137, 6018-6025. [CrossRef] [PubMed]

97. McCormick, T.M.; Calitree, B.D.; Orchard, A.; Kraut, N.D.; Bright, F.V.; Detty, M.R.; Eisenberg, R. Reductive Side of Water Splitting in Artificial Photosynthesis: New Homogeneous Photosystems of Great Activity and Mechanistic Insight. J. Am. Chem. Soc. 2010, 132, 15480-15483. [CrossRef] [PubMed]

98. Dong, J.; Wang, M.; Zhang, P.; Yang, S.; Liu, J.; Li, X.; Sun, L. Promoting Effect of Electrostatic Interaction between a Cobalt Catalyst and a Xanthene Dye on Visible-Light-Driven Electron Transfer and Hydrogen Production. J. Phys Chem. C 2011, 115, 15089-15096. [CrossRef]

99. Mori, K.; Kakudo, H.; Yamashita, H. Creation of Nickel-Based Active Species within a Macroreticular Acidic Resin: A Noble-Metal-Free Heterogeneous Catalyst for Visible-Light-Driven $\mathrm{H}_{2}$ Evolution from Water. ACS Catal. 2014, 4, 4129-4135. [CrossRef]

100. Yong, Y.; Wang, M.; Xue, L.; Zhang, F.; Chen, L.; Ahlquist, M.S.G.; Sun, L. Nickel Complex with Internal Bases as Efficient Molecular Catalyst for Photochemical $\mathrm{H}_{2}$ Production. ChemSusChem 2014, 7, 2889-2897. [CrossRef] [PubMed]

101. Cui, H.-H.; Wang, J.-Y.; Hu, M.-Q.; Ma, C.-B.; Wen, H.-M.; Song, X.-W.; Chen, C.-N. Efficient photo-driven hydrogen evolution by binuclear nickel catalysts of different coordination in noble-metal-free systems. Dalton Trans. 2013, 42, 8684-8691. [CrossRef] [PubMed]

102. Lazarides, T.; McCormick, T.; Du, P.; Luo, G.; Lindley, B.; Eisenberg, R. Making Hydrogen from Water Using a Homogeneous System Without Noble Metals. J. Am. Chem. Soc. 2009, 131, 9192-9194. [CrossRef] [PubMed]

103. Zhang, P.; Wang, M.; Dong, J.; Li, X.; Wang, F.; Wu, L.; Sun, L. Photocatalytic Hydrogen Production from Water by Noble-Metal-Free Molecular Catalyst Systems Containing Rose Bengal and the Cobaloximes of $\mathrm{BF}_{x}$-Bridged Oxime Ligands. J. Phys Chem. C 2010, 114, 15868-15874. [CrossRef]

104. Zhang, W.; Hong, J.; Zheng, J.; Huang, Z.; Zhou, J.; Xu, R. Nickel-Thiolate Complex Catalyst Assembled in One Step in Water for Solar $\mathrm{H}_{2}$ Production. J. Am. Chem. Soc. 2011, 133, 20680-20683. [CrossRef] [PubMed]

105. Li, X.; Wang, M.; Zhang, S.; Pan, J.; Na, Y.; Liu, J.; Åkermark, B.; Sun, L. Noncovalent Assembly of a Metalloporphyrin and an Iron Hydrogenase Active-Site Model: Photo-Induced Electron Transfer and Hydrogen Generation. J. Phys. Chem. B 2008, 112, 8198-8202. [CrossRef] [PubMed]

106. Li, X.; Wang, M.; Chen, L.; Wang, X.; Dong, J.; Sun, L. Photocatalytic Water Reduction and Study of the Formation of $\mathrm{Fe}^{\mathrm{I}} \mathrm{Fe}^{0}$ Species in Diiron Catalyst Sytems. ChemSusChem 2012, 5, 913-919. [CrossRef] [PubMed]

107. Orain, C.; Quentel, F.; Gloaguen, F. Photocatalytic Hydrogen Production Using Models of the Iron-Iron Hydrogenase Active Site Dispersed in Micellar Solution. ChemSusChem 2014, 7, 638-643. [CrossRef] [PubMed]

108. Jian, J.-X.; Ye, C.; Wang, X.-Z.; Wen, M.; Li, Z.-J.; Li, X.-B.; Chen, B.; Tung, C.-H.; Wu, L.-Z. Comparison of $\mathrm{H}_{2}$ photogeneration by [FeFe]-hydrogenase mimics with $\mathrm{CdSe} Q \mathrm{QDs}$ and $\mathrm{Ru}(\mathrm{bpy})_{3} \mathrm{Cl}_{2}$ in aqueous solution. Energy Environ. Sci. 2016, 9, 2083-2089. [CrossRef] 
109. Lv, H.; Ruberu, P.A.; Fleischauer, V.E.; Brennessel, W.W.; Neidig, M.L.; Eisenberg, R. Catalytic Light-Driven Generation of Hydrogen from Water by Iron Dithiolene Complexes. J. Am. Chem. Soc. 2016, 138, 11654-11663. [CrossRef] [PubMed]

110. Tropmann, S.; König, B. Functionalized Vesicles with Co-Embedded CdSe Quantum Dots and [FeFe]-Hydrogenase Mimic for Light-Driven Hydrogen Production. ChemistrySelect 2016, 1, 1405-1409. [CrossRef]

111. Jian, J.-X.; Liu, Q.; Li, Z.-J.; Wang, F.; Li, X.-B.; Li, C.-B.; Liu, B.; Meng, Q.-Y.; Chen, B.; Feng, K.; et al. Chitosan confinement enhances hydrogen photogeneration from a mimic of the diiron subsite of [FeFe]-hydrogenase. Nat. Commun. 2013, 4, 2695. [CrossRef] [PubMed]

112. Caputo, C.A.; Wang, L.; Beranek, R.; Reisner, E. Carbon nitride-TiO ${ }_{2}$ hybrid modified with hydrogenase for visible light driven hydrogen production. Chem. Sci. 2015, 6, 5690-5694. [CrossRef]

113. Edel, A.; Marnot, P.A.; Sauvage, J.P. Photochemical reduction of water via energy transfer from a copper(I) complex. Nouv. J. Chim. 1984, 8, 495-498.

114. Armaroli, N.; Accorsi, G.; Holler, M.; Moudam, O.; Nierengarten, J.-F.; Zhou, Z.; Wegh, R.T.; Welter, R. Highly Luminescent $\mathrm{Cu}^{\mathrm{I}}$ Complexes for Light-Emitting Electrochemical Cells. Adv. Mater. 2006, 18, 1313-1316. [CrossRef]

115. Cuttell, D.G.; Kuang, S.M.; Fanwick, P.E.; McMillin, D.R.; Walton, R.A. Simple Cu(I) Complexes with Unprecedented Excited-State Lifetimes. J. Am. Chem. Soc. 2002, 124, 6-7. [CrossRef] [PubMed]

116. Harkins, S.B.; Peters, J.C. A Highly Emissive $\mathrm{Cu}_{2} \mathrm{~N}_{2}$ Diamond Core Complex Supported by a [PNP] ${ }^{-}$Ligand. J. Am. Chem. Soc. 2005, 127, 2030-2031. [CrossRef] [PubMed]

117. Smith, C.S.; Branham, C.W.; Marquardt, B.J.; Mann, K.R. Oxygen Gas Sensing by Luminescence Quenching in Crystals of $\mathrm{Cu}$ (xantphos)(phen) ${ }^{+}$Complexes. J. Am. Chem. Soc. 2010, 132, 14079-14085. [CrossRef] [PubMed]

118. Kuang, S.-M.; Cuttell, D.G.; McMillin, D.R.; Fanwick, P.E.; Walton, R.A. Synthesis and Structural Characterization of $\mathrm{Cu}(\mathrm{I})$ and $\mathrm{Ni}(\mathrm{II})$ Complexes that Contain the Bis[2-(diphenylphosphino)phenyl]ether Ligand. Novel Emission Properties for the Cu(I) Species. Inorg. Chem. 2002, 41, 3313-3322. [CrossRef] [PubMed]

119. Alonso-Vante, N.; Nierengarten, J.-F.; Sauvage, J.-P. Spectral Sensitization of Large-band-gap Semiconductors (Thin Films and Ceramics) by a Carboxylated Bis(1,10-Phenanthroline)copper(I) Complex. J. Chem. Soc. Dalton Trans. 1994, 1649-1654. [CrossRef]

120. Bessho, T.; Constable, E.C.; Graetzel, M.; Hernandez Redondo, A.; Housecroft, C.E.; Kylberg, W.; Nazeeruddin, M.K.; Neuburger, M.; Schaffner, S. An element of surprise-Efficient copper-functionalized dye-sensitized solar cells. Chem. Commun. 2008, 3717-3719. [CrossRef] [PubMed]

121. Bergmann, L.; Friedrichs, J.; Mydlack, M.; Baumann, T.; Nieger, M.; Bräse, S. Outstanding luminescence from neutral copper(I) complexes with pyridyl-tetrazolate and phosphine ligands. Chem. Commun. 2013, 49, 6501-6503. [CrossRef] [PubMed]

122. Costa, R.D.; Ortí, E.; Bolink, H.J.; Monti, F.; Accorsi, G.; Armaroli, N. Luminescent Ionic Transition-Metal Complexes for Light-Emitting Electrochemical Cells. Angew. Chem. Int. Ed. 2012, 51, 8178-8211. [CrossRef] [PubMed]

123. Sandroni, M.; Kayanuma, M.; Planchat, A.; Szuwarski, N.; Blart, E.; Pellegrin, Y.; Daniel, C.; Boujtita, M.; Odobel, F. First application of the HETPHEN concept to new heteroleptic bis(diimine) copper(I) complexes as sensitizers in dye sensitized solar cells. Dalton Trans. 2013, 42, 10818-10827. [CrossRef] [PubMed]

124. Yuasa, J.; Dan, M.; Kawai, T. Phosphorescent properties of metal-free diphosphine ligands and effects of copper binding. Dalton Trans. 2013, 42, 16096-16101. [CrossRef] [PubMed]

125. Czerwieniec, R.; Kowalski, K.; Yersin, H. Highly efficient thermally activated fluorescence of a new rigid $\mathrm{Cu}(\mathrm{I})$ complex $[\mathrm{Cu}(\mathrm{dmp}) \text { (phanephos)] }]^{+}$. Dalton Trans. 2013, 42, 9826-9830. [CrossRef] [PubMed]

126. Zhang, P.; Wang, M.; Yang, Y.; Yao, T.; Sun, L. A Molecular Copper Catalyst for Electrochemical Water Reduction with a Large Hydrogen-Generation Rate Constant in Aqueous Solution. Angew. Chem. Int. Ed. 2014, 53, 13803-13807. [CrossRef] [PubMed]

127. Chen, Z.; Meyer, T.J. Copper(II) Catalysis of Water Oxidation. Angew. Chem. Int. Ed. 2013, 52, 700-703. [CrossRef] [PubMed] 
128. Barnett, S.M.; Goldberg, K.I.; Mayer, J.M. A soluble copper-bipyridine water-oxidation electrocatalyst. Nat. Chem. 2012, 4, 498-502. [CrossRef] [PubMed]

129. Zhang, T.; Wang, C.; Liu, S.; Wang, J.-L.; Lin, W. A Biomimetic Copper Water Oxidation Catalyst with Low Overpotential. J. Am. Chem. Soc. 2014, 136, 273-281. [CrossRef] [PubMed]

130. Coggins, M.K.; Zhang, M.-T.; Chen, Z.; Song, N.; Meyer, T.J. Single-Site Copper(II) Water Oxidation Electrocatalysis: Rate Enhancements with $\mathrm{HPO}_{4}{ }^{2-}$ as a Proton Acceptor at $\mathrm{pH}$ 8. Angew. Chem. Int. Ed. 2014, 53, 12226-12230. [CrossRef] [PubMed]

131. Chen, Z.; Kang, P.; Zhang, M.-T.; Stoner, B.R.; Meyer, T.J. $\mathrm{Cu}(\mathrm{II}) / \mathrm{Cu}(0)$ electrocatalyzed $\mathrm{CO}_{2}$ and $\mathrm{H}_{2} \mathrm{O}$ splitting. Energy Environ. Sci. 2013, 6, 813-817. [CrossRef]

132. Choi, H.-J.; Kang, M. Hydrogen production from methanol/water decomposition in a liquid photosystem using the anatase structure of $\mathrm{Cu}$ loaded $\mathrm{TiO}_{2}$. Int. J. Hydrogen Energy 2007, 32, 3841-3848. [CrossRef]

133. Yoong, L.S.; Chong, F.K.; Dutta, B.K. Development of copper-doped $\mathrm{TiO}_{2}$ photocatalyst for hydrogen production under visible light. Energy 2009, 34, 1652-1661. [CrossRef]

134. Xu, S.; Sun, D.D. Significant improvement of photocatalytic hydrogen generation rate over $\mathrm{TiO}_{2} \mathrm{with}$ deposited CuO. Int. J. Hydrogen Energy 2009, 34, 6096-6104. [CrossRef]

135. Sakata, Y.; Yamamoto, T.; Okazaki, T.; Imamura, H.; Tsuchiya, S. Generation of Visible Light Response on the Photocatalyst of a Copper Ion Containing $\mathrm{TiO}_{2}$. Chem. Lett. 1998, 27, 1253-1254. [CrossRef]

136. Kumar, D.P.; Shankar, M.V.; Kumari, M.M.; Sadanandam, G.; Srinivas, B.; Durgakumari, V. Nano-size effects on $\mathrm{CuO} / \mathrm{TiO}_{2}$ catalysts for highly efficient $\mathrm{H}_{2}$ production under solar light irradiation. Chem. Commun. 2013, 49, 9443-9445. [CrossRef] [PubMed]

137. Paracchino, A.; Laporte, V.; Sivula, K.; Grätzel, M.; Thimsen, E. Highly active oxide photocathode for photoelectrochemical water reduction. Nat. Mater. 2011, 10, 456-461. [CrossRef] [PubMed]

138. Barreca, D.; Fornasiero, P.; Gasparotto, A.; Gombac, V.; Maccato, C.; Montini, T.; Tondello, E. The Potential of Supported $\mathrm{Cu}_{2} \mathrm{O}$ and $\mathrm{CuO}$ Nanosystems in Photocatalytic $\mathrm{H}_{2}$ Production. ChemSusChem 2009, 2, $230-233$. [CrossRef] [PubMed]

139. Somasundaram, S.; Chenthamarakshan, C.R.N.; de Tacconi, N.R.; Rajeshwar, K. Photocatalytic production of hydrogen from electrodeposited $\mathrm{p}-\mathrm{Cu}_{2} \mathrm{O}$ film and sacrificial electron donors. Int. J. Hydrogen Energy 2007, 32, 4661-4669. [CrossRef]

140. McCusker, C.E.; Castellano, F.N. Design of a Long-Lifetime, Earth-Abundant, Aqueous Compatible Cu(I) Photosensitizer Using Cooperative Steric Effects. Inorg. Chem. 2013, 52, 8114-8120. [CrossRef] [PubMed]

141. Kaeser, A.; Mohankumar, M.; Mohanraj, J.; Monti, F.; Holler, M.; Cid, J.-J.; Moudam, O.; Nierengarten, I.; Karmazin-Brelot, L.; Duhayon, C.; et al. Heteroleptic Copper(I) Complexes Prepared from Phenanthroline and Bis-Phosphine Ligands. Inorg. Chem. 2013, 52, 12140-12151. [CrossRef] [PubMed]

142. Chen, J.-L.; Cao, X.-F.; Wang, J.-Y.; He, L.-H.; Liu, Z.-Y.; Wen, H.-R.; Chen, Z.-N. Synthesis, Characterization, and Photophysical Properties of Heteroleptic Copper(I) Complexes with Functionalized 3-(2'-Pyridyl)-1,2,4-triazole Chelating Ligands. Inorg. Chem. 2013, 52, 9727-9740. [CrossRef] [PubMed]

143. Huang, J.; Buyukcakir, O.; Mara, M.W.; Coskun, A.; Dimitrijevic, N.M.; Barin, G.; Kokhan, O.; Stickrath, A.B.; Ruppert, R.; Tiede, D.M.; et al. Highly Efficient Ultrafast Electron Injection from the Singlet MLCT Excited State of Copper(I) Diimine Complexes to $\mathrm{TiO}_{2}$ Nanoparticles. Angew. Chem. Int. Ed. 2012, 51, 12711-12715. [CrossRef] [PubMed]

144. Luo, S.-P.; Mejía, E.; Friedrich, A.; Pazidis, A.; Junge, H.; Surkus, A.-E.; Jackstell, R.; Denurra, S.; Gladiali, S.; Lochbrunner, S.; et al. Photocatalytic Water Reduction with Copper-Based Photosensitizers: A Noble-Metal-Free System. Angew. Chem. Int. Ed. 2013, 52, 419-423. [CrossRef] [PubMed]

145. Mejía, E.; Luo, S.-P.; Karnahl, M.; Friedrich, A.; Tschierlei, S.; Surkus, A.-E.; Junge, H.; Gladiali, S.; Lochbrunner, S.; Beller, M. A Noble-Metal-Free System for Photocatalytic Hydrogen Production from Water. Chem. Eur. J. 2013, 19, 15972-15978. [CrossRef] [PubMed]

146. Karnahl, M.; Mejía, E.; Rockstroh, N.; Tschierlei, S.; Luo, S.-P.; Grabow, K.; Kruth, A.; Brüser, V.; Junge, H.; Lochbrunner, S.; et al. Photocatalytic Hydrogen Production with Copper Photosensitizer-Titanium Dioxide Composites. ChemCatChem 2014, 6, 82-86. [CrossRef]

147. Khnayzer, R.S.; McCusker, C.E.; Olaiya, B.S.; Castellano, F.N. Robust Cuprous Phenanthroline Sensitizer for Solar Hydrogen Photocatalysis. J. Am. Chem. Soc. 2013, 52, 14068-14070. [CrossRef] [PubMed]

148. Montalti, M.; Credi, A.; Prodi, L.; Gandolfi, T. Chemical Actinometry. In Handbook of Photochemistry, 3rd ed.; CRC: Boca Raton, FL, USA, 2011; pp. 601-616. 
149. Carneiro, Z.A.; de Moraes, J.C.B.; Rodrigues, F.P.; de Lima, R.G.; Curti, C.; da Rocha, Z.N.; Paulo, M.; Bendhack, L.M.; Tedesco, A.C.; Formiga, A.L.B.; et al. Photocytotoxic activity of a nitrosyl phthalocyanine ruthenium complex-A system capable of producing nitric oxide and singlet oxygen. J. Inorg. Biochem. 2011, 105, 1035-1043. [CrossRef] [PubMed]

150. Heussner, K.; Peuntinger, K.; Rockstroh, N.; Nye, L.C.; Ivanovic-Burmazovic, I.; Rau, S.; Streb, C. Solution and solid-state interactions in a supramolecular ruthenium photosensitizer-polyoxometalate aggregate. Chem. Commun. 2011, 47, 6852-6854. [CrossRef] [PubMed]

151. La Ganga, G.; Puntoriero, F.; Campagna, S.; Bazzan, I.; Berardi, S.; Bonchio, M.; Sartorel, A.; Natali, M.; Scandola, F. Light-driven water oxidation with a molecular tetra-cobalt(III) cubane cluster. Faraday Discuss. 2012, 155, 177-190. [CrossRef] [PubMed]

152. Pan, Q.J.; Guo, Y.R.; Li, L.; Odoh, S.O.; Fu, H.G.; Zhang, H.X. Structures, spectroscopic properties and redox potentials of quaterpyridyl $\mathrm{Ru}(\mathrm{II})$ photosensitizer and its derivatives for solar energy cell: A density functional study. Phys. Chem. Chem. Phys. 2011, 13, 14481-14489. [CrossRef] [PubMed]

153. Shimakoshi, H.; Nishi, M.; Tanaka, A.; Chikama, K.; Hisaeda, Y. Photocatalytic function of a polymer-supported $\mathrm{B}_{12}$ complex with a ruthenium trisbipyridine photosensitizer. Chem. Commun. 2011, 47, 6548-6550. [CrossRef] [PubMed]

154. McMillin, D.R.; Kirchhoff, J.R.; Goodwin, K.V. Exciplex quenching of photo-excited copper complexes. Coord. Chem. Rev. 1985, 64, 83-92. [CrossRef]

155. Riesgo, E.C.; Hu, Y.-Z.; Bouvier, F.; Thummel, R.P.; Scaltrito, D.V.; Meyer, G.J. Crowded Cu(I) Complexes Involving Benzo[ $h]$ quinoline: $\pi$-Stacking Effects and Long-Lived Excited States. Inorg. Chem. 2001, 40, 3413-3422. [CrossRef] [PubMed]

156. Tschierlei, S.; Karnahl, M.; Rockstroh, N.; Junge, H.; Beller, M.; Lochbrunner, S. Substitution-Controlled Excited State Processes in Heteroleptic Copper(I) Photosensitizers Used in Hydrogen Evolving Systems. ChemPhysChem 2014, 17, 3709-3713. [CrossRef] [PubMed]

157. Sun, Y.-Y.; Wang, H.; Chen, N.-Y.; Lennox, A.J.J.; Friedrich, A.; Xia, L.-M.; Lochbrunner, S.; Junge, H.; Beller, M.; Zhou, S.; et al. Efficient Photocatalytic Water Reduction Using In Situ Generated Knölker's Iron Complexes. ChemCatChem 2016, 8, 2340-2344. [CrossRef]

158. Weng, F.; Wang, W.-G.; Wang, X.-J.; Wang, H.-Y.; Tung, C.-H.; Wu, L.-Z. A Highly Efficient Photocatalytic System for Hydrogen Production by a Robust Hydrogenase Mimic in an Aqueous Solution. Angew. Chem. Int. Ed. 2011, 50, 3193-3197. [CrossRef] [PubMed]

159. Bokarev, S.I.; Bokareva, O.S.; Kühn, O. A theoretical perspective on charge transfer in photocatalysis. The example of Ir-based systems. Coord. Chem. Rev. 2015, 304-305, 133-145. [CrossRef]

160. Hollmann, D.; Gärtner, F.; Ludwig, R.; Barsch, E.; Junge, H.; Blug, M.; Hoch, S.; Beller, M.; Brückner, A. Insights into the Mechanism of Photocatalytic Water Reduction by DFT-Supported In Situ EPR/Raman Spectroscopy. Angew. Chem. Int. Ed. 2011, 50, 10246-10250. [CrossRef] [PubMed]

161. Fischer, S.; Bokareva, O.S.; Barsch, E.; Bokarev, S.I.; Kühn, O.; Ludwig, R. Mechanistic Study of Photocatalytic Hydrogen Generation with Simple Iron Carbonyls as Water Reduction Catalysts. ChemCatChem 2016, 8, 404-411. [CrossRef]

162. Bokarev, S.I.; Hollmann, D.; Pazidis, A.; Neubauer, A.; Radnik, J.; Kühn, O.; Lochbrunner, S.; Junge, H.; Beller, M.; Brückner, A. Spin density distribution after electron transfer from triethylamine to an $\left[\operatorname{Ir}(\mathrm{ppy})_{2}(\mathrm{bpy})\right]^{+}$photosensitizer during photocatalytic water reduction. Phys. Chem. Chem. Phys. 2014, 16, 4789-4796. [CrossRef] [PubMed]

163. Neubauer, A.; Grell, G.; Friedrich, A.; Bokarev, S.I.; Schwarzbach, P.; Gärtner, F.; Surkus, A.-E.; Junge, H.; Beller, M.; Kühn, O.; et al. Electron- and Energy-Transfer Processes in a Photocatalytic System Based on an Ir(III)-Photosensitizer and an Iron Catalyst. J. Phys. Chem. Lett. 2014, 5, 1355-1360. [CrossRef] [PubMed]

164. Walther, B.; Hartung, H.; Böttcher, H.-C.; Baumeister, U.; Böhland, U.; Reinhold, J.; Sieler, J.; Ladriere, J.; Schiebel, H.M. Unexpected reaction of $\left[\mathrm{Ni}(\mathrm{CO})_{4-n}\left(\mathrm{R}_{2} \mathrm{PCl}\right)_{n}\right]\left(n=1,2 ; \mathrm{R}=\mathrm{Bu}^{t}, \mathrm{Cy}, \mathrm{Ph}\right)$ with $\mathrm{Na}_{2}\left[\mathrm{Fe}_{2}(\mathrm{CO})_{8}\right]$. Synthesis and electronic structure of the anions $\left[\mathrm{Fe}_{2}(\mu-\mathrm{CO})(\mathrm{CO})_{6}\left(\mu-\mathrm{PR}_{2}\right)\right]^{-}$and their reactions with $\mathrm{H}^{+}$and $\left[\mathrm{M}\left(\mathrm{PPh}_{3}\right)\right]^{+}(\mathrm{M}=\mathrm{Cu}, \mathrm{Ag}, \mathrm{Au})$. Polyhedron 1991, 10, 2423-2435. [CrossRef]

165. Fischer, S.; Hollmann, D.; Tschierlei, S.; Karnahl, M.; Rockstroh, N.; Barsch, E.; Schwarzbach, P.; Luo, S.-P.; Junge, H.; Beller, M.; et al. Death and Rebirth: Photocatalytic Hydrogen Production by a Self-Organizing Copper-Iron System. ACS Catal. 2014, 4, 1845-1849. [CrossRef] 
166. Lennox, A.J.J.; Fischer, S.; Jurrat, M.; Luo, S.-P.; Rockstroh, N.; Junge, H.; Ludwig, R.; Beller, M. Copper-Based Photosensitisers in Water Reduction: A More Efficient In Situ Formed System and Improved Mechanistic Understanding. Chem. Eur. J. 2016, 22, 1233-1238. [CrossRef] [PubMed]

167. Tschierlei, S.; Neubauer, A.; Rockstroh, N.; Karnahl, M.; Schwarzbach, P.; Junge, H.; Beller, M.; Lochbrunner, S. Ultrafast excited state dynamics of iridium(III) complexes and their changes upon immobilisation onto titanium dioxide layers. Phys. Chem. Chem. Phys. 2016, 18, 10682-10687. [CrossRef] [PubMed] 